\title{
LakeSST: Lake Skin Surface Temperature in French inland water bodies for 1999-2016 from Landsat archives
}

\author{
Jordi Prats ${ }^{1}$, Nathalie Reynaud ${ }^{1}$, Delphine Rebière ${ }^{1,3}$, Tiphaine Peroux ${ }^{1}$, Thierry Tormos ${ }^{2}$, and \\ Pierre-Alain Danis ${ }^{2}$ \\ ${ }^{1}$ UR RECOVER, Pôle AFB-Irstea hydroécologie plans d'eau, Irstea, 13182, Aix-en-Provence, France \\ ${ }^{2}$ Agence Française pour la Biodiversité, Pôle AFB-Irstea hydroécologie plans d'eau, \\ 13182 Aix-en-Provence, France \\ ${ }^{3}$ CEREMA, Direction Centre-Est, 63017 Clermont-Ferrand, France
}

Correspondence: Jordi Prats (jordi.prats@irstea.fr, jordipratsrodriguez@gmail.com)

Received: 5 December 2017 - Discussion started: 15 December 2017

Revised: 9 March 2018 - Accepted: 15 March 2018 - Published: 11 April 2018

\begin{abstract}
The spatial and temporal coverage of the Landsat satellite imagery make it an ideal resource for the monitoring of water temperature over large territories at a moderate spatial and temporal scale at a low cost. We used Landsat 5 and Landsat 7 archive images to create the Lake Skin Surface Temperature (LakeSST) data set, which contains skin water surface temperature data for 442 French water bodies (natural lakes, reservoirs, ponds, gravel pit lakes and quarry lakes) for the period 1999-2016. We assessed the quality of the satellite temperature measurements by comparing them to in situ measurements and taking into account the cool skin and warm layer effects. To estimate these effects and to investigate the theoretical differences between the freshwater and seawater cases, we adapted the COARE 3.0 algorithm to the freshwater environment. We also estimated the warm layer effect using in situ data. At the reservoir of Bimont, the estimated cool skin effect was about -0.3 and $-0.6^{\circ} \mathrm{C}$ most of time, while the warm layer effect at $0.55 \mathrm{~m}$ was negligible on average, but could occasionally attain several degrees, and a cool layer was often observed in the night. The overall RMSE of the satellite-derived temperature measurements was about $1.2{ }^{\circ} \mathrm{C}$, similar to other applications of satellite images to estimate freshwater surface temperatures. The LakeSST data can be used for studies on the temporal evolution of lake water temperature and for geographical studies of temperature patterns. The LakeSST data are available at https://doi.org/10.5281/zenodo.1193745.
\end{abstract}

Copyright statement. The author's copyright for this publication is transferred to Irstea.

\section{Introduction}

Surface water temperature (SWT) is a key water quality parameter driving the ecological status of lakes (e.g. Shuter and Post, 1990; O'Reilly et al., 2003). Monitoring SWT is therefore an important issue, especially in the context of climate changes. Nevertheless the SWTs assessed over a national network of water quality monitoring are usually not frequent enough or are limited to a restricted number of lakes. For example, in France, the implementation of the
Water Framework European Directive implies the monitoring of 475 lakes but just 4 times a year only 1 year every 3 years, and such a frequency of observations is too low to detect long-term trends. To improve the water quality monitoring and to survey climate change effects, networks dedicated to continuously monitor temperature at high frequencies (e.g. hourly time step) in the water column (1$4 \mathrm{~m}$ in vertical resolution) are used (Marcé et al., 2016), e.g. the Networking Lake Observatories in Europe (NETLAKE, https://www.dkit.ie/netlake) (Laas et al., 2016) or the Global Lake Observatory Network (GLEON, gleon.org) (Hamilton et al., 2015). However, such large-scale networks mainly focus on large lakes and reservoirs while medium and small 
water bodies are more abundant than large water bodies (Verpoorter et al., 2014). In France, 15 relatively small water bodies (surface between 0.45 and $22 \mathrm{~km}^{2}$ ) are currently monitored. Research projects may also provide useful data. But in spite of the current efforts to make research data more accessible, it is still difficult to locate and access these data. In addition, the use of different instrumentation, methodologies and formats may require lengthy tasks of homogenisation and data-wrangling prior to their use.

Satellite thermal infrared (TIR) imagery, such as Landsat, can complete this monitoring effort by providing homogenous information on surface water temperature over large territories at a moderate spatial and temporal scale. Moreover, remote sensing monitoring can collect information from inaccessible and non-instrumented water bodies, and long-term and climate change studies can benefit from historical information starting in the 1980s (e.g. Schneider and Hook, 2010; Politi et al., 2012; Torbick et al., 2016). Because of its advantages, this technology has been increasingly applied to freshwater ecology in recent years (Dörnhöfer and Oppelt, 2016): satellite images have been used to study the water temperature of fluvial reaches (Lalot et al., 2015), reservoirs (Lamaro et al., 2013; Martí-Cardona et al., 2016), lakes (Marti-Cardona et al., 2008; Crosman and Horel, 2009) and crater lakes (Trunk and Bernard, 2008), as well as to monitor the thermal plumes from power plants (Zoran, 2011).

However, satellite-derived measurements correspond to the instant water temperature at the top of the surface $(\sim 10$ $20 \mu \mathrm{m}$ deep), known as skin temperature (Donlon et al., 1999; Kawai and Wada, 2007). Skin temperatures can differ from SWT because the thermal structure of the first metres of the water column is not uniform under all conditions. Atsea measurements of the skin surface temperature are usually lower than the temperature of the underlying water (cool skin effect), showing a dependence on wind speed (Fairall et al., 1996a; Minnett et al., 2011), and similar differences have been observed in freshwater environments (Cardenas et al., 2008). A warm near-surface layer can also appear on calm and sunny days, without necessarily excluding the presence of a cool skin (Donlon et al., 1999). Under such conditions the thermal gradient can attain several degrees in the upper few metres of the water column (Ward, 2006).

Nevertheless, satellite-derived water temperature data (skin temperatures) are relevant and sufficient to (i) demonstrate spatial and temporal patterns of surface water temperature for reservoirs and lakes (e.g. Schneider et al., 2009; Schneider and Hook, 2010; Prats and Danis, 2015), (ii) complement the data used for the calibration and validation of hydrodynamic and water quality models of lakes (Andréassian et al., 2012; Prats and Danis, 2017), and (iii) improve the estimation of surface heat and gas fluxes (Lofgren and Zhu, 2000) that is important to understand the thermal behaviour of lakes (Henderson-Sellers, 1986).

This data paper presents the data set LakeSST of skin surface water temperature for 442 French lake water bod- ies derived from Landsat thermal infrared imagery. LakeSST was produced as part of a project funded by the French National Office for Water and Aquatic Environments (ONEMA, now part of the French Agency for Biodiversity, AFB) to assess the advantages and limitations of satellite data to monitor the water temperature of inland water bodies. After recalling what is meant by surface temperature in this paper and the methodology used to derive skin temperatures from Landsat thermal infrared bands fully described by $\mathrm{Si}$ mon et al. (2014), the precision and accuracy of the data set LakeSST are reported in view of surface temperature assessment. First, relations between skin temperature and surface temperature are dealt with in detail. Second, the overall accuracy of LakeSST is assessed (i) by using water bodies located in overlapping areas of the images, and (ii) by comparing them to in situ continuous temperature measurements in five water bodies.

\section{Study area and field data}

\subsection{Study area}

The original objective of this data set was to obtain long-term measurements of French lakes which are monitored under the Water Framework Directive. Initially this comprised a total of 475 lakes of surface area larger than $0.5 \mathrm{~km}^{2}$ in metropolitan France, including 64 natural lakes, 328 reservoirs, 43 ponds, 34 gravel pit lakes and 6 quarry lakes. However, the final data set contains data for 442 lakes, the rest having been excluded because of insufficient availability of data (Fig. 1). The complete list of water bodies with geographical coordinates is included in the file 01_lake_data.txt of the data set. The geographical and morphometric data were extracted from the French lake database (PLAN_DEAU) maintained by the AFB-Irstea consortium for R\&D on Water Bodies Hydroecology at Aix-en-Provence (France).

\subsection{In situ data for quality assessment}

Satellite-based water temperature estimations were compared to continuous in situ measurements of water temperature at different depths at five French water bodies (Table 1, Fig. 1). The in situ measurements were provided by the ONEMA and are part of a French continuous monitoring network of lake water temperature. Water temperature was measured through chains of HOBO Water Temp Pro V2/U22-001 thermistors installed on a buoy at the deepest part of the water body. The thermistors have a precision of $\pm 0.2^{\circ} \mathrm{C}$ between 0 and $50^{\circ} \mathrm{C}$, and a resolution of $0.02^{\circ} \mathrm{C}$ at $25^{\circ} \mathrm{C}$. Temperatures were measured at depths between $0.5 \mathrm{~m}$ and the bottom at intervals of 1 to $4 \mathrm{~m}$, depending on the depth (measurements were more spaced in the hypolimnion). Measurement frequency varied from once every $15 \mathrm{~min}$ to once every hour, depending on the water body and time period. In the analysis, a common $1 \mathrm{~h}$ time step was used for all water bodies. 
Table 1. Comparison of satellite-based temperature estimations made using the algorithm by Jiménez-Muñoz et al. (2009) and corrected for skin and warm layer effects $\left(T_{\mathrm{sml}}^{*}\right.$ and $\left.T_{0.50 \mathrm{~m}}^{*}\right)$ to in situ measurements (temperature at $0.50 \mathrm{~m}, T_{0.50 \mathrm{~m}}$, and average temperature of the surface mixed layer, $T_{\mathrm{sml}}$ ). ME is the mean error (satellite - field data), $\rho$ is the correlation coefficient and RMSE is the root mean square error. ME statistically different from zero at $\alpha=0.05$ are indicated with an asterisk.

\begin{tabular}{llrrrrr|rrr}
\hline Water & Water & Period & Number & \multicolumn{2}{c}{$T_{\text {sml }}^{*} \sim T_{\text {sml }}$} & \multicolumn{2}{c}{$T_{0.50 \mathrm{~m}}^{*} \sim T_{0.50 \mathrm{~m}}$} \\
\cline { 6 - 10 } $\begin{array}{l}\text { body } \\
\text { code }\end{array}$ & body & name & & of meas. & $\begin{array}{r}\text { ME } \\
\left({ }^{\circ} \mathrm{C}\right)\end{array}$ & $\rho$ & $\begin{array}{r}\text { RMSE } \\
\left({ }^{\circ} \mathrm{C}\right)\end{array}$ & $\begin{array}{r}\text { ME } \\
\left({ }^{\circ} \mathrm{C}\right)\end{array}$ & $\begin{array}{r}\rho \\
\text { RMSE } \\
\left({ }^{\circ} \mathrm{C}\right)\end{array}$ \\
\hline AUL13 & Aulnes & 29 Dec 2013-19 Mar 2014 & 2 & -0.72 & 1.00 & 0.72 & -0.72 & 1.00 & 0.73 \\
BIM13 & Bimont & 24 Feb 2014-19 Nov 2016 & 28 & 0.40 & 0.97 & 1.19 & 0.18 & 0.98 & 1.04 \\
LPC38 & Pierre-Châtel & 23 Aug 2013-19 Dec 2015 & 11 & $-0.81^{*}$ & 0.98 & 1.28 & $-0.97 *$ & 0.98 & 1.41 \\
PAV63 & Pavin & 24 Oct 2013-28 Sep 2015 & 15 & -0.10 & 0.98 & 1.05 & -0.22 & 0.98 & 1.05 \\
SCR04 & Sainte-Croix & 31 Jul 2013-30 Dec 2016 & 36 & 0.41 & 0.97 & 1.49 & 0.03 & 0.98 & 1.24 \\
All lakes & & 31 Jul 2013-30 Dec 2016 & 92 & 0.16 & 0.97 & 1.30 & -0.11 & 0.98 & 1.17 \\
\hline
\end{tabular}

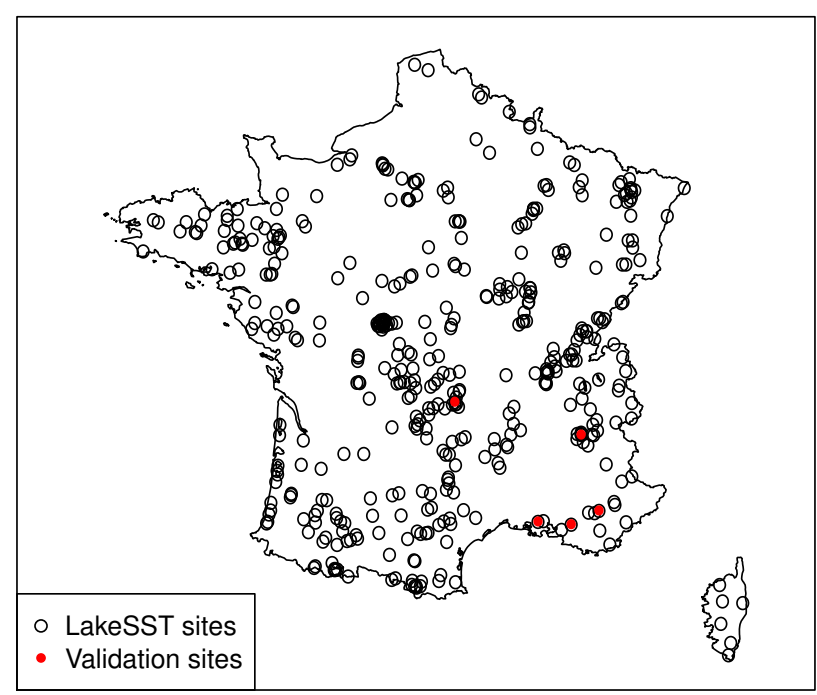

Figure 1. Location of the water bodies included in LakeSST and validation sites.

In one of the water bodies, the reservoir of Bimont (southeast of France, at $10 \mathrm{~km}$ from Aix-en-Provence), an additional thermistor chain was installed, with the same type of thermistors dedicated to monitor in more detail the temperature gradient in the subsurface. The thermistors were placed at depths between 0.01 and $0.55 \mathrm{~m}$ (at $0.01,0.05,0.10,0.15$, $0.20,0.25,0.35,0.45,0.55 \mathrm{~m}$ ) between the 21 February 2014 and the 3 May 2016.

In addition to in situ data, meteorological data were gathered for the five French water bodies from the SAFRAN reanalysis data (Quintana-Seguí et al., 2008; Vidal et al., 2010), available for the study period at the nearest grid point at a daily resolution. The following variables were extracted: air temperature, specific humidity, wind speed, liquid precipitation, solid precipitation, downwelling longwave radiation and incoming solar radiation. An adiabatic correction of $-0.0065^{\circ} \mathrm{C} \mathrm{m}^{-1}$ was applied to air temperature data to account for the difference in altitudes between the measurement point and the reservoir of Bimont. Additionally, we calculated solar elevation and extraterrestrial solar radiation following Lenoble (1993). We calculated the daily clearness index as

$k_{\mathrm{t}}=R_{\mathrm{s}} / R_{\mathrm{e}}$,

where $R_{\mathrm{S}}$ is the daily solar radiation at the Earth surface and $R_{\mathrm{e}}$ is the extraterrestrial daily solar radiation through a plane parallel to the surface.

Finally, for the reservoir of Bimont, Météo-France kindly provided hourly meteorological data (air temperature, relative humidity, wind speed, solar radiation) measured at the meteorological station of Aix-en-Provence $\left(43^{\circ} 31^{\prime} 42^{\prime \prime} \mathrm{N}\right.$, $5^{\circ} 25^{\prime} 24^{\prime \prime} \mathrm{E}$ ).

\section{Methods}

\subsection{Definitions of surface temperature}

As mentioned in the Introduction, the thermal structure of the first metres of the water column is not uniform. To avoid confusion, several definitions of surface temperature have been proposed for the marine environment, depending on the depth of measurement (Donlon et al., 2007; Kawai and Wada, 2007). We adapt (and adopt) these definitions for the freshwater case:

- The interface surface temperature $\left(T_{\text {int }}\right)$ is the theoretical temperature at the infinitesimally wide air-water interface.

- The skin surface temperature $\left(T_{\text {skin }}\right)$ is the temperature of the first $\sim 10-20 \mu \mathrm{m}$ below the interface and it is dominated by heat conduction. It is measured with infrared radiometers.

- The sub-skin surface temperature $\left(T_{\text {subskin }}\right)$ is the temperature of the first $1-1.5 \mathrm{~mm}$ of the water column. It is measured with microwave radiometers. 
- The temperature at depth $z\left(T_{z}\right)$, also known as (bulk) surface temperature, is the temperature measured at the said depth. It is the temperature measured by in situ sensors (thermistors, CTD, etc.). The French continuous monitoring network proposes using $T_{0.5 \mathrm{~m}}$ to monitor lake surface temperature (Rebière et al., 2014) and in the freshwater literature different reference depths are used for surface temperature, from $10-15 \mathrm{~cm}$ to several metres (e.g. Kettle et al., 2004; Toffolon et al., 2014).

- Finally, we will define the temperature of the surface mixed layer $(\mathrm{SML})\left(T_{\mathrm{sml}}\right)$ as the average temperature between the surface and the top of the metalimnion. The SML temperature $T_{\mathrm{sml}}$ is calculated by integrating temperature measurements made with a thermistor chain or water quality profiler at different depths between the surface and the top of the metalimnion.

The bulk surface temperature can be related to the skin surface temperature through

$T_{\text {skin }}=T_{z}+\Delta T_{\mathrm{c}}+\Delta T_{\mathrm{w}}$

where $\Delta T_{\mathrm{c}}$ is the cool skin effect and $\Delta T_{\mathrm{w}}$ is the warm layer effect. Both effects are related to thermal heterogeneities in the temperature distribution near the surface. The warm layer forms during the day and is due to surface stratification caused by the absorption of solar radiation in the first metres of the water column (Fairall et al., 1996a). The magnitude of the warm layer effect can attain several degrees (Fairall et al., 1996a; Kawai and Wada, 2007; Gentemann and Minnett, 2008). The cool skin effect is almost always present and arises from the cooling of the first millimetres of the water column because of the joint action of longwave radiation, sensible and latent heat fluxes (Fairall et al., 1996a). Its magnitude is of -0.1 to $-0.5^{\circ} \mathrm{C}$ (Fairall et al., 1996a; Donlon et al., 2002).

\subsection{Deriving skin temperature from Landsat imagery}

The thermal infrared band of both Landsat 5 TM (Thematic Mapper) and Landsat 7 ETM+ (Enhanced Thematic Mapper Plus) instruments were used for deriving skin temperature. Although Landsat 8 was already operative at the beginning of this study, we did not process its thermal infrared images at first, because of stray light artefacts in the thermalband measurements (Montanaro et al., 2014). An algorithm has recently been implemented that largely solves this problem (Gerace and Montanaro, 2017) and we expect to include Landsat 8 data in future versions of the data set.

The TIR band (band 6) of Landsat 5 TM and Landsat 7 ETM+ sensors measured emitted radiation at wavelengths of $10.40-12.50 \mu \mathrm{m}$. Both satellites have similar orbits, with a delay of 8 days, and they fly over France at 10:0010:30 UTC. Two consecutive scenes overlap at $5 \%$ of their surface and are taken with a delay of $23.92 \mathrm{~s}$ (NASA, 2011).
The TM instrument acquired Band 6 data at a $120 \mathrm{~m}$ resolution and the ETM+ instrument acquired Band 6 data at a $60 \mathrm{~m}$ resolution. TIR Landsat data were extracted from Landsat Climate Data Records (CDR) data. Landsat CDR consist of surface reflectance products from the Landsat archive (Masek et al., 2006) which are freely available from the United States Geological Survey (USGS). Thermal infrared data are provided as top-of-atmosphere (TOA) brightness temperature images resampled via cubic convolution to a pixel size of $30 \mathrm{~m}$. Useful mask layers for clouds, cloud shadows, adjacent clouds, snow, land and water, and quality flags are also provided. The noise-equivalent delta temperature of Landsat measurements is $0.2-0.3^{\circ} \mathrm{C}$ (Barsi et al., 2003).

TIR data must be corrected for emissivity and atmospheric effects if it is to be quantitatively useful (see Li et al., 2013). On the one hand, emissivity variations for water-only pixels of relatively small and calm inland waterbodies are insignificant in most practical applications. Atmospheric correction, on the other hand, is required to compensate for atmospheric absorption and emission effects. Two possibilities are available for correcting single-band TIR images. The first is through the use of the radiative transfer equation (RTE) (e.g. Hook et al., 2004), in which transmissivity of the atmosphere, upwelling atmospheric radiance and downwelling atmospheric radiance are obtained through the use of radiative transfer modelling codes. This method, however, requires in situ radiosounding data obtained near the study area and near the acquisition time of the image as input (Jiménez-Muñoz and Sobrino, 2003). The second possibility is to apply singlechannel (SC) correction algorithms which are based on approximations of the RTE. Despite being less accurate, these algorithms crucially avoid dependence on in situ radiosounding data and are therefore better suited for satellite imagery archive studies (Sobrino et al., 2004). Jiménez-Muñoz and Sobrino (2003), in particular, have developed an operational algorithm which relies solely on atmospheric water vapour content as ancillary data. This algorithm has been applied to several lakes and reservoirs (Lamaro et al., 2013; Simon et al., 2014; Allan et al., 2016) and to the Guadalquivir River estuary (Díaz-Delgado et al., 2010). The algorithm was originally implemented by Simon et al. (2014) and used to produce the LakeSST data set.

Total column water vapour data, required by the algorithm, were extracted from the ERA-Interim reanalysis data set (Dee et al., 2011) provided by the ECMWF (European Centre for Medium-Range Weather Forecasts) at a resolution of $0.25^{\circ}$. The water vapour content at the time the image was taken was interpolated from data at 06:00 and 12:00 UTC. During the preprocessing phase, we extracted the valid pixels for each water body and image. For each image the preprocessing included the following steps:

- extraction of the TIR band, masks and metadata from the original hdf files; 
- selection of water pixels using land-water mask and vector file containing the water body outline;

- suppression of unexploitable pixels by application of mask products associated to the image.

For the image processing, brightness temperature in the remaining pixels was converted to surface temperature following the single-channel algorithm proposed by JiménezMuñoz and Sobrino (2003), adapted to Landsat images (Jiménez-Muñoz et al., 2009). For further details on the algorithm or its calibration for Landsat thermal bands, please refer to these articles.

The algorithm is sensitive to variations of emissivity: a $1 \%$ decrease in emissivity produced an increase in estimated temperature of $0.4-0.6^{\circ} \mathrm{C}$. In this work the emissivity of water was assumed to be $\varepsilon=0.9885$ (Lamaro et al., 2013). However, emissivity can vary depending on factors such as the view angle and the concentration of suspended sediments. The emissivity of water varies with the zenith angle, mainly for angles above $40^{\circ}$ (Masuda et al., 1988). The satellite Landsat 7 orbits the Earth at a height of $705 \mathrm{~km}$, at a speed of $7.5 \mathrm{~km} \mathrm{~s}^{-1}$ (NASA, 2011). At this speed, the variation in the viewing angle during the $23.92 \mathrm{~s}$ between two successive images is $\sim 14^{\circ}$, so that there should not be a significant effect on temperature linked to the variation of emissivity with the zenith angle. The emissivity of water can also be affected by the concentration of suspended sediments, resulting in estimation errors of as much as $1{ }^{\circ} \mathrm{C}$ for a variation of emissivity of 0.01 (Wen-Yao et al., 1987). However, for freshwater the effect is only important for very high concentrations of suspended sediments $\left(\geq 10 \mathrm{~g} \mathrm{~L}^{-1}\right)$ (Wen-Yao et al., 1987).

The algorithm is applicable for a range of atmospheric water vapour content between 0.5 and $2 \mathrm{~g} \mathrm{~cm}^{-2}$; for vapour contents outside this range, bias may be important (JiménezMuñoz et al., 2009). However, the algorithm is not very sensitive to variations in atmospheric water vapour content: a $50 \%$ decrease in the value of $w$ produced a decrease in the estimated temperature of $0.2-0.3{ }^{\circ} \mathrm{C}$.

A negative buffer was applied to the water bodies of each image to filter out pixels close to the bank and thus avoid potentially land-water mixed pixels. The width of the buffer was $170 \mathrm{~m}$ for Landsat 5 and $85 \mathrm{~m}$ for Landsat 7 , which approximately corresponds to the length of the pixel diagonal. All images for a given water body were then reprojected to a common Reference Coordinate System (WGS84, EPSG:4326) and resampled by cubic convolution to a common $30 \mathrm{~m} \times 30 \mathrm{~m}$ grid. Images for which the water vapour content did not belong to the range of applicability of the algorithm $\left(0.5-2 \mathrm{~g} \mathrm{~cm}^{-2}\right)$ were discarded. Images with negative values were also discarded (due to undetected ice cover, etc.). The presence of clouds caused important biases in the temperature estimations. To avoid this bias, we discarded all images for which the daily clearness index was less than 0.6. Summary statistics were calculated for each image: number of valid pixels, median temperature, mean temperature, stan- dard deviation, minimum temperature, maximum temperature, $25 \%$ percentile and $75 \%$ percentile.

\subsection{Assessment of the relation between skin temperature and surface temperature}

The applicability of surface temperatures measured by satellite to study the temperature of the surface mixed layer of lakes depends on the relation between surface temperature and subsurface temperatures. The skin temperature differs slightly from water temperature in the first metres of the water column because of cool skin and warm layer effects. Three methods were implemented to assess these effects.

\subsubsection{Warm layer estimations based on field measurements}

We used data from the $0.55 \mathrm{~m}$ chain installed at the reservoir of Bimont to assess the relation between surface temperature and temperature at $0.55 \mathrm{~m}$. The instrumentation used was not adapted to measure the cool skin effect, since the surface thermistor measured temperature at a depth of about $1 \mathrm{~cm}$, below the cool skin. However, the Bimont data could be used to measure the warm layer effect. We calculated the warm layer effect at $0.55 \mathrm{~m}$ as follows:

$\Delta T_{\mathrm{w}}(0.55 \mathrm{~m})=T_{0.01 \mathrm{~m}}-T_{0.55 \mathrm{~m}}$.

\subsubsection{Cool skin effect estimations depending on wind speed}

Several parameterisations have been proposed to estimate $\Delta T_{\mathrm{c}}$ as a function of wind speed measured at $10 \mathrm{~m}$ above the ground surface $U_{10}$. Using data for the reservoir of Bimont, we applied the parameterisations obtained for the sea by Donlon et al. (2002):

$\Delta T_{\mathrm{c}}=-0.14-0.30 \exp \left(-0.27 U_{10}\right) ;$

Horrocks et al. (2003):

$\Delta T_{\mathrm{c}}=-0.11-0.35 \exp \left(-0.28 U_{10}\right) ;$

Gentemann and Minnett (2008):

$\Delta T_{\mathrm{c}}=-0.13-0.22 \exp \left(-0.350 U_{10}\right) ;$

and Minnett et al. (2011):

$\Delta T_{\mathrm{c}}=-0.130-0.724 \exp \left(-0.350 U_{10}\right)$.

\subsubsection{Application of the COARE algorithm adapted to the freshwater environment}

There are several models that take into account the cool skin and the warm layer effect at the sea (Price et al., 1986; 

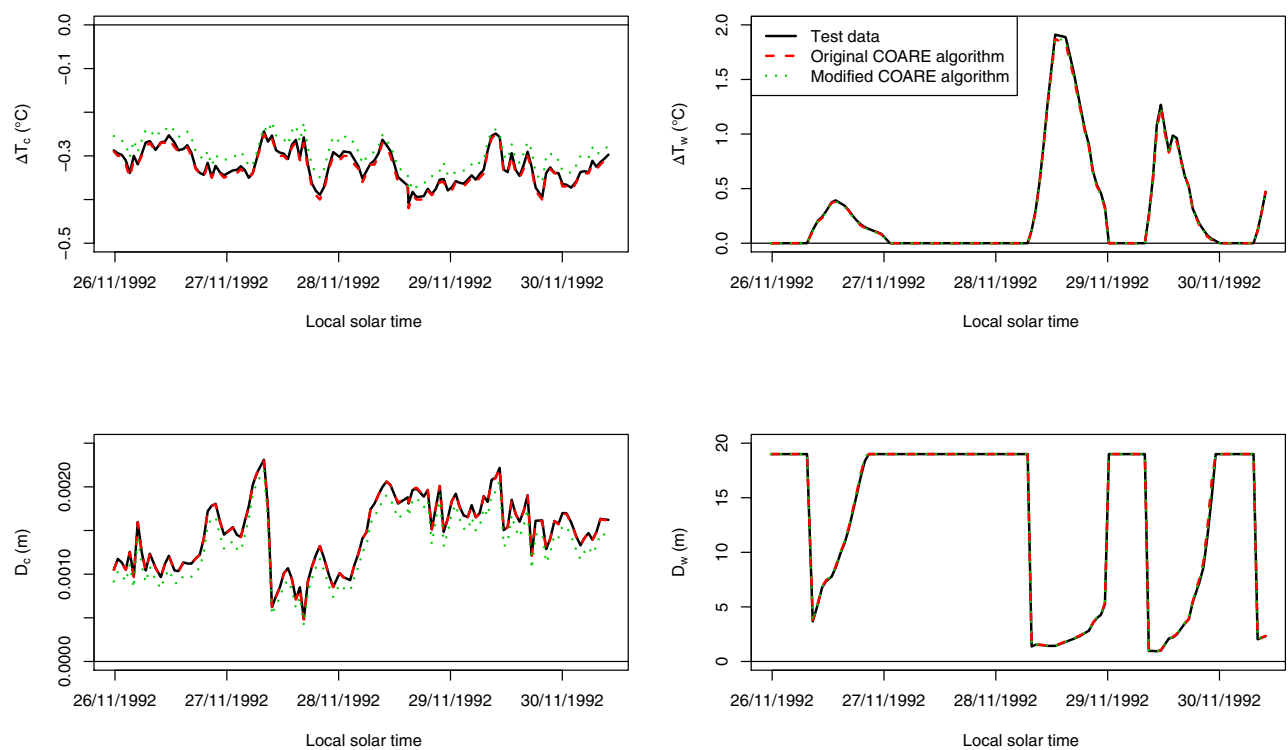

Figure 2. Validation of the implementation of bulk flux COARE algorithm and its modification: cool skin effect $\left(\Delta T_{\mathrm{c}}\right)$, cool skin depth $\left(D_{\mathrm{c}}\right)$, warm layer effect $\left(\Delta T_{\mathrm{W}}\right)$ and warm layer depth $\left(D_{\mathrm{w}}\right)$. Data are 4 days of Moana Wave COARE test data.

Kantha and Clayson, 1994; Fairall et al., 1996a; Kawai and Kawamura, 2000; Gentemann et al., 2009). To analyse both the cool skin and the warm layer effects for the case of the reservoir of Bimont, we used the model proposed by Fairall et al. (1996a) and implemented in the COARE bulk flux algorithm (Fairall et al., 1996b), that depends on the surface heat (shortwave irradiance, longwave irradiance, latent and sensible heat exchange) and moment fluxes (wind shear). We implemented the model in $\mathrm{R}$ based on the code of the COARE bulk flux algorithm version 3.0 (Fairall et al., 2003). We validated the implementation of the algorithm using 4 days of Moana Wave COARE test data (Fig. 2). The FORTRAN code and test data were obtained from ftp://ftp1.esrl.noaa.gov/psd3/cruises/NTAS_2009/RHB/ Scientific_analysis/programs/VOCALS2008_programs_ leg1/coare/bulkalg/cor3_0/. In the original parameterisation, the physical properties of water (viscosity, density, thermal expansivity, salinity expansivity and thermal conductivity) are constant and adapted to the seawater case. We modified the algorithm to calculate the physical properties of water as a function of temperature and salinity using expressions provided by Sharqawy et al. (2010). An R file (Coare_3_0.R) with the implementation of the model is supplied in the Supplement. The simulation of $\Delta T_{\mathrm{w}}$ for the test data was almost equal for both algorithms. However, the algorithm with physical properties of water depending on temperature and salinity simulated a less intense cool skin effect (with an average difference of $0.03^{\circ} \mathrm{C}$ ). The difference was due to a too-high value of the kinematic viscosity of $10^{-6} \mathrm{~m}^{2} \mathrm{~s}^{-1}$ in the original COARE algorithm. According to the tables published by Chen et al. (1973), the viscosity of seawater is $0.84 \times 10^{-6} \mathrm{~m}^{2} \mathrm{~s}^{-1}$ at $30^{\circ} \mathrm{C}$ and $1.0 \times 10^{-6} \mathrm{~m}^{2} \mathrm{~s}^{-1}$ at $20^{\circ} \mathrm{C}$. The average temperature of the test data at a depth of $6 \mathrm{~m}$ was $29.4^{\circ} \mathrm{C}$, and the average value of kinematic viscosity of water in the modified version of the algorithm was $0.85 \times 10^{-6} \mathrm{~m}^{2} \mathrm{~s}^{-1}$.

We applied the modified COARE algorithm to the data of the reservoir of Bimont, assuming a salinity of $0 \mathrm{~g} \mathrm{~kg}^{-1}$ and a maximum depth of the warm layer of $5 \mathrm{~m}$ (approximately the seasonal thermocline depth). We also calculated the cool skin and warm layer effects for the seawater case, assuming a salinity of $35 \mathrm{~g} \mathrm{~kg}^{-1}$, using the same data, since it is of interest to know if other algorithms applied at sea are applicable to the freshwater case and with which limitations. The use of salinity-dependent functions for the physical properties of water, allowed us to test whether differences in the behaviour in the surface temperature between freshwater and seawater were theoretically expected because of the difference in salinity.

\subsection{Assessment of the precision and accuracy of satellite-based surface water temperature measurements}

Consecutive satellite scenes overlap by $5 \%$. As a consequence, at these overlapping zones repeated temperature measurements are available with just a few seconds of difference. We used the data from 45 water bodies located in the overlapping zones between consecutive scenes to estimate the precision of satellite-based surface water temperatures.

The assessment of the accuracy of satellite measurements was made by comparing them to in situ SML temperature and temperature at $0.5 \mathrm{~m}$ for 5 lakes with continuous moni- 


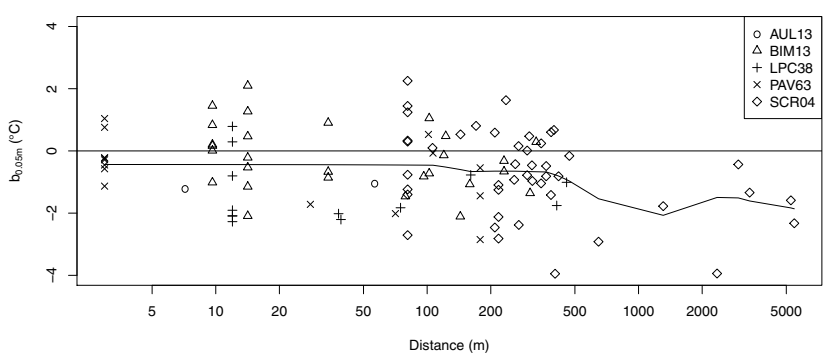

Figure 3. Measurements and LOWESS of the bias of $T_{0.50 \mathrm{~m}}$ as a function of the distance between the measurement point and the nearest valid pixel in the satellite image.

toring (Table 1). We calculated the bias for the five water bodies with continuous measurements as the difference between field measurements and satellite temperature measurements at the nearest pixel $\left(T_{\text {sat }}\right)$ as

$b_{0.50 \mathrm{~m}}=T_{\text {sat }}-T_{0.50 \mathrm{~m}}$,

$b_{\mathrm{sml}}=T_{\mathrm{sat}}-T_{\mathrm{sml}}$,

where $b_{0.50 \mathrm{~m}}$ is the bias in relation to temperature at $0.50 \mathrm{~m}$ and $b_{\mathrm{sml}}$ is bias in relation to the SML temperature. The bias depended on the distance of the measurement location to the centre of the nearest pixel, because of spatial variability of the surface temperature (Fig. 3). Absolute bias increased for distances greater than $500 \mathrm{~m}$. Most of the satellite-field data pairs separated by more than $500 \mathrm{~m}$ correspond to SCR04, the largest water body. Satellite temperatures measured near the field measurement point at this reservoir (near the dam) were warmer than in the open waters. To exclude this distance effect, we kept for further analyses the data pairs separated by less than $400 \mathrm{~m}$.

A more robust validation method would be the comparison of corrected satellite radiances to in situ measurements with a thermal radiometer. We did not apply this method because we did not have surface temperature data measured by radiometer yet. This analysis will be considered in future works.

\subsection{Software used}

We analysed the data using Python 2.7 and R 3.2.0 (R Core Team, 2015). We used the Python packages NumPy (van der Walt et al., 2011), Matplotlib (Hunter, 2007) and Pandas (McKinney, 2010) and the R packages MASS (Venables and Ripley, 2002) and rLakeAnalyzer (Winslow et al., 2016).

\section{Cool skin and warm layer effects}

\subsection{Theoretical salinity effects}

The application of the COARE model revealed differences in the cool skin effect caused by the difference in salinity between the freshwater and seawater cases (Fig. 4a, c). For low wind speeds (approx. $<4 \mathrm{~m} \mathrm{~s}^{-1}$ ) the skin effect was (a)

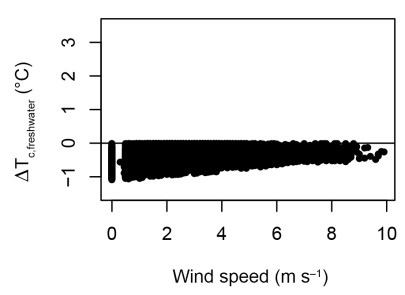

(c)
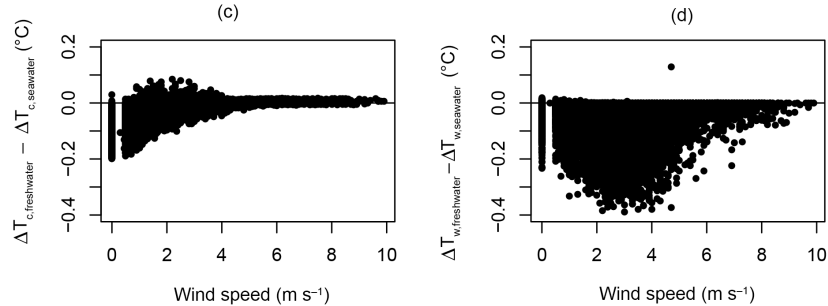

Figure 4. Cool skin (a) and warm layer (b) effect estimated by the model proposed by Fairall et al. (1996a) using the data for Bimont, and the difference in cool skin (c) and warm skin (d) effect between freshwater (salinity $=0 \mathrm{~g} \mathrm{~kg}^{-1}$ ) and seawater $\left(35 \mathrm{~g} \mathrm{~kg}^{-1}\right.$ ) according to the same model and meteorological conditions.

more important (by $0.03^{\circ} \mathrm{C}$ on average) and the cool skin was thicker (by $0.2 \mathrm{~mm}$ on average) in the freshwater simulation. The difference could attain $0.2{ }^{\circ} \mathrm{C}$ for very low wind speeds. Above $4 \mathrm{~m} \mathrm{~s}^{-1}$, the two cases show a very similar behaviour, with average differences in cool skin effect and thickness of $0.002{ }^{\circ} \mathrm{C}$ and $0.02 \mathrm{~mm}$, respectively. For the higher wind speeds shear-induced turbulent heat exchange dominates, while for the lower wind speeds molecular and convective heat exchange dominate (Fairall et al., 1996a; Donlon et al., 1999, 2002). The simulated warm layer effect was more intense for the seawater case than for the freshwater case, especially for low wind speeds (Fig. 4b, d). For wind speeds below $6 \mathrm{~m} \mathrm{~s}^{-1}$, the difference was $0.03^{\circ} \mathrm{C}$ on average, but could amount to almost $0.4^{\circ} \mathrm{C}$. These differences do not take into account the effect of different solar absorption in the water column. Also, differences in the wave field and the atmospheric boundary layer in lakes could have an effect on skin temperatures (Wilson et al., 2013).

\subsection{Cool skin effect}

For high wind speeds, the different wind-dependent cool skin parameterisations converge to cool skin effect values of about $-0.2{ }^{\circ} \mathrm{C}$ (Fig. 5). The uncertainty is higher for low wind speeds, where convective and molecular heat transfer are more important than the effect of wind shear (Fairall et al., 1996a; Donlon et al., 2002) and the use of more complex parameterisations is advised (Donlon et al., 2002). This is especially relevant for inland water bodies, where wind speeds are smaller than those found in the open sea (Wilson et al., 2013). 


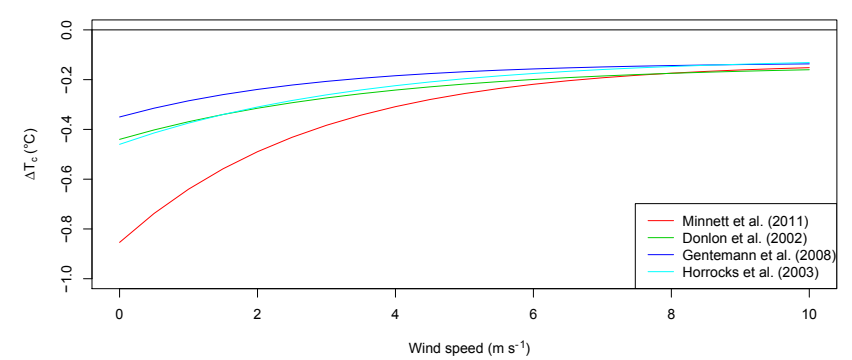

Figure 5. Cool skin effect $\left(\Delta T_{\mathrm{c}}\right)$ as a function of wind speed according to several empirical parameterisations.
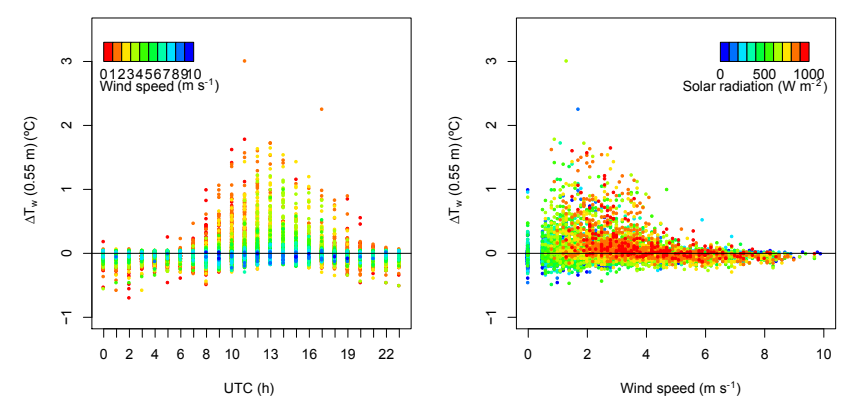

Figure 6. Warm layer effect $\left(\Delta T_{\mathrm{W}}\right)$ at $0.55 \mathrm{~m}$ at the reservoir of Bimont as a function of the time of measurement, wind speed and solar radiation, 21 February 2014 to 31 July 2016.

According to the results of the COARE algorithm, the mean estimated $\Delta T_{\mathrm{c}}$ was $-0.46^{\circ} \mathrm{C}$, the maximum $\Delta T_{\mathrm{c}}$ was $-1.08^{\circ} \mathrm{C}$ and the first and third quartile were -0.31 and $0.61{ }^{\circ} \mathrm{C}$, respectively (Fig. 4a). The estimated cool skin depth was mostly $2-3 \mathrm{~mm}$ (first quartile: $1.8 \mathrm{~mm}$; third quartile: $2.8 \mathrm{~mm}$ ), although occasionally the algorithm predicted skin depths deeper than $1 \mathrm{~cm}$ (maximum skin depth of $1.65 \mathrm{~cm}$ ). During the day, the cool skin could disappear. These values are consistent with measurements at Lake Tahoe, with median skin effects of -0.34 to $-0.46^{\circ} \mathrm{C}$ at night (Wilson et al., 2013). Measurements taken in crater lakes (Oppenheimer, 1997) and cooling ponds (Wesely, 1979; Adams et al., 1990) show that cool skin effects can attain -1 to $-3^{\circ} \mathrm{C}$ in hot and heated inland water bodies.

\subsection{Warm layer effect}

The measured warm layer effect at $0.55 \mathrm{~m}$ was mostly positive during the day, with maximum values around midday (Fig. 6). For wind speeds above $7 \mathrm{~m} \mathrm{~s}^{-1}$, the daily variability in $\Delta T_{\mathrm{w}}(0.55 \mathrm{~m})$ disappeared. This is consistent with a limit between 6 and $10 \mathrm{~m} \mathrm{~s}^{-1}$ found by other authors (Gentemann et al., 2003; Gentemann and Minnett, 2008). The more important surface warming (of almost $2{ }^{\circ} \mathrm{C}$ ) occurred for low winds and high solar radiation, in accordance with many studies at the sea (Donlon et al., 1999, 2002; Kawai and Wada, 2007; Gentemann and Minnett, 2008). The average observed $\Delta T_{\mathrm{w}}(0.55 \mathrm{~m})$ was $0.0^{\circ} \mathrm{C}$, the maximum observed

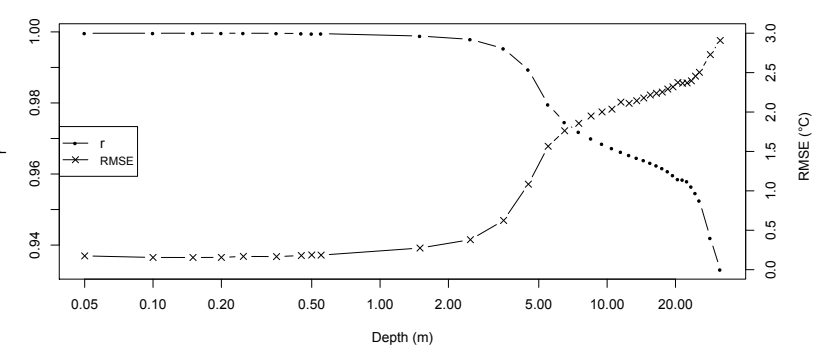

Figure 7. Coefficient of determination and RMSE of the SML temperature in relation to temperature at other depths.

$\Delta T_{\mathrm{w}}(0.55 \mathrm{~m})$ was $3.0^{\circ} \mathrm{C}$, and the minimum $\Delta T_{\mathrm{w}}(0.55 \mathrm{~m})$ was $-0.7^{\circ} \mathrm{C}$. At night $\Delta T_{\mathrm{w}}(0.55 \mathrm{~m})$ was mostly negative, indicating the presence of a cool layer caused by convective cooling (Imberger, 1985).

Using the same data, as well as the data of the fulllength thermistor chain, we analysed the relation between the surface temperature (below the cool skin) and $T_{\mathrm{sml}}$, the temperature of the surface mixed layer. The average difference between the surface and the surface mixed layer was $\Delta T_{\mathrm{w}}(\mathrm{sml})=0.11^{\circ} \mathrm{C}$. The correlation between $T_{\mathrm{sml}}$ and the temperature at different depths was almost constant and near to 1 between the surface and a depth of $1.5 \mathrm{~m}$ (Fig. 7). The RMSE we would incur was less than $0.3^{\circ} \mathrm{C}$ if we used any of these temperatures as an estimation of the SML temperature. Below a depth of $2.5 \mathrm{~m}$ the RMSE sharply increased and the correlation coefficient sharply decreased, with an inflection point at a depth of about $5 \mathrm{~m}$ corresponding approximately to the seasonal thermocline depth.

On average the warm layer effect predicted by the COARE algorithm was small (mean of $0.25^{\circ} \mathrm{C}$; first quantile of $0.00^{\circ} \mathrm{C}$; third quantile of $0.26^{\circ} \mathrm{C}$ ), but it could attain maximum values of about $3{ }^{\circ} \mathrm{C}$ for wind speeds of $2-4.5 \mathrm{~m} \mathrm{~s}^{-1}$ (Fig. 4b). At 10:00 UTC, around the time of satellite overpass, the estimated average warm layer effect was $0.34^{\circ} \mathrm{C}$. These results contrast with the warm layer observations. The maximum values observed for this range of wind speeds were less than $2{ }^{\circ} \mathrm{C}$ in general (Fig. 6) and the average observed warm layer effect was $0.0^{\circ} \mathrm{C}$. Following Fairall et al. (1996a), we estimated the warm layer effect at the depth $z_{\mathrm{r}}$ as

$\Delta T_{\mathrm{w}}\left(z_{\mathrm{r}}\right)=\Delta T_{\mathrm{w}} \frac{z_{\mathrm{r}}}{D_{\mathrm{T}}}$,

where $D_{\mathrm{T}}$ is the estimated depth of the warm layer, assuming a linear profile, and compared them to the field measurements. For $z_{\mathrm{r}}=0.55 \mathrm{~m}$, the coefficient of correlation between measurements and estimations was 0.45 and the root mean square error was $0.22^{\circ} \mathrm{C}$, with the model overestimating the surface thermal gradient. The highest correlation between estimated and measured warm layer effect was found for $z_{\mathrm{r}}=2.50 \mathrm{~m}$, with a correlation coefficient of 0.78 and 
$\mathrm{RMSE}=0.32^{\circ} \mathrm{C}$. The discrepancies between the simulation and the measurements can be attributed to several factors:

- The model proposed by Fairall et al. (1996a) does not allow for negative warm layers (or cool layers). Some of the effects of convective cooling are included in the definition of the cool skin, but they are constrained to the upper millimetres of the water column.

- The meteorological data used to force the COARE algorithm were measured at about $10 \mathrm{~km}$ from the study site. Although air temperature data were corrected for altitude effects, local micrometeorological conditions at the reservoir of Bimont are probably different to those measured at the meteorological station of Aix-en-Provence (Prats et al., 2018b). For example, the wind field might be affected by local orography and relative humidity could be affected by the presence of the reservoir.

- The parameterisation of the solar radiation absorption might be inadequate. Ohlmann and Siegel (2000) proposed a parameterisation of the transmission of solar radiation in the ocean which took into account the effect of the vertical distribution of chlorophyll in the water column, the cloud amount and the solar zenith angle. The implementation of this parameterisation into the COARE bulk flux algorithm improved the quality of the sea surface temperature simulations (Ohlmann and Siegel, 2000; Wick et al., 2005). The COARE 3.0 solar absorption parameterisation might be particularly illadapted to the freshwater case, since freshwater is typically less transparent than open sea water.

- The distortion of the temperature field by the measuring device and platforms may cause errors in surface temperature measurements (Kawai and Kawamura, 2000). Kawai et al. (2009) found differences exceeding $1.0^{\circ} \mathrm{C}$ between measurements taken at a depth of $0.20 \mathrm{~m}$ at different sides of a surface-moored buoy $2.4 \mathrm{~m}$ in diameter. The differences were greater when diurnal warming was important. Since the buoy used for the $0.55 \mathrm{~m}$ chain (a polystyrene plate $0.75 \mathrm{~m}$ wide) was much less intrusive, we expect the platform effect to be less important. In addition, a comparison between the $0.55 \mathrm{~m}$ sensor of the $0.55 \mathrm{~m}$ chain and the 0.5 sensor of the nearby full-length chain revealed only small differences.

\section{Quality assessment of LakeSST}

\subsection{Effect of the time of measurement}

In the previous sections we analysed the relation between the surface temperature and $T_{0.55} \mathrm{~m}$ during the day. However, the pass-over time of Landsat above a given Earth zone is quite constant. During the study period, the Landsat satellites passed above the reservoir of Bimont between 09:54 UTC

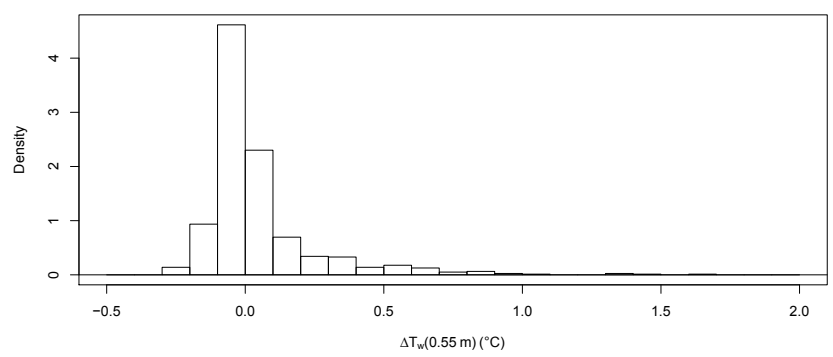

Figure 8. Histogram of $\Delta T_{\mathrm{W}}(0.55 \mathrm{~m})$ at the reservoir of Bimont at 10:00 UTC, 21 February 2014 to 24 April 2016.

and 10:26 UTC. In this section we analyse $\Delta T_{\mathrm{W}}(0.55 \mathrm{~m})$ at 10:00 UTC.

At 10:00 UTC, $\Delta T_{\mathrm{w}}(0.55 \mathrm{~m})$ was very small for most measurements at the reservoir of Bimont (Fig. 8): the mean $\Delta T_{\mathrm{w}}(0.55 \mathrm{~m})$ was $0.05^{\circ} \mathrm{C}$, the median $\Delta T_{\mathrm{w}}(0.55 \mathrm{~m})$ was $0.00{ }^{\circ} \mathrm{C}$ and the standard error was $0.21^{\circ} \mathrm{C}$. The maximum observed value of $\Delta T_{\mathrm{w}}(0.55 \mathrm{~m})$ at $10: 00 \mathrm{UTC}$ was $1.6^{\circ} \mathrm{C}$, but $\Delta T_{\mathrm{W}}(0.55 \mathrm{~m})$ was higher than $0.5^{\circ} \mathrm{C}$ only $5 \%$ of the time. Similarly, the mean $\Delta T_{\mathrm{w}}(\mathrm{sml})$ was $0.11^{\circ} \mathrm{C}$, the median $\Delta T_{\mathrm{w}}(\mathrm{sml})$ was $0.06^{\circ} \mathrm{C}$ and the standard error was $0.16^{\circ} \mathrm{C}$.

The previous values are valid for all-cloud situations; however, because of the way satellite images are taken there is a selection bias: surface temperature measurements were only selected here for clear skies $\left(k_{\mathrm{t}} \geq 0.6\right)$. Under such conditions, the average $\Delta T_{\mathrm{w}}(0.55 \mathrm{~m})$ at $10: 00 \mathrm{UTC}$ was $0.07^{\circ} \mathrm{C}$, the median was $0.00{ }^{\circ} \mathrm{C}$ and the standard error was $0.24^{\circ} \mathrm{C}$; and for the surface mixed layer, the average $\Delta T_{\mathrm{w}}(\mathrm{sml})$ at 10:00 UTC was $0.12^{\circ} \mathrm{C}$, the median was $0.07^{\circ} \mathrm{C}$ and the standard error was $0.17^{\circ} \mathrm{C}$.

\subsection{Precision of satellite-based surface water temperature measurements}

Figure 9 shows the differences in temperature between successive scenes for individual pixels. The differences in temperature for individual pixels in successive scenes is unbiased with a median difference of $0.00{ }^{\circ} \mathrm{C}$ (mean: $-0.08^{\circ} \mathrm{C}$; first quartile: $-0.0007^{\circ} \mathrm{C}$; third quartile: $0.0007^{\circ} \mathrm{C}$ ) and a root mean square error of $0.20^{\circ} \mathrm{C}$. There is a feeble variation of the RMSE between groups, whether the data are grouped by month $\left(0.28\right.$ to $0.49^{\circ} \mathrm{C}$, Fig. $\left.9 \mathrm{~d}\right)$, season $\left(0.36\right.$ to $0.40^{\circ} \mathrm{C}$, Fig. 9e) or year $\left(0.25\right.$ to $0.52^{\circ} \mathrm{C}$, Fig. $\left.9 f\right)$. In contrast, occasionally there can be important variations of temperature differences within a given group (e.g. -2.5 to $+7.3^{\circ} \mathrm{C}$ for the month of April, Fig. 9a). Temperature differences remain within the range from -2 to $+2{ }^{\circ} \mathrm{C}$ for most years. However, in some notable cases (especially the years 2007 and 2011, Fig. 9c) the maximum differences could exceed $5^{\circ} \mathrm{C}$. The most important biases (more than $3^{\circ} \mathrm{C}$ ) were concentrated on a few particular dates and water bodies (Table 2 ). In all cases, these biases were localised near the water edge (Fig. 10), often on the west side of the water body, but sometimes also 

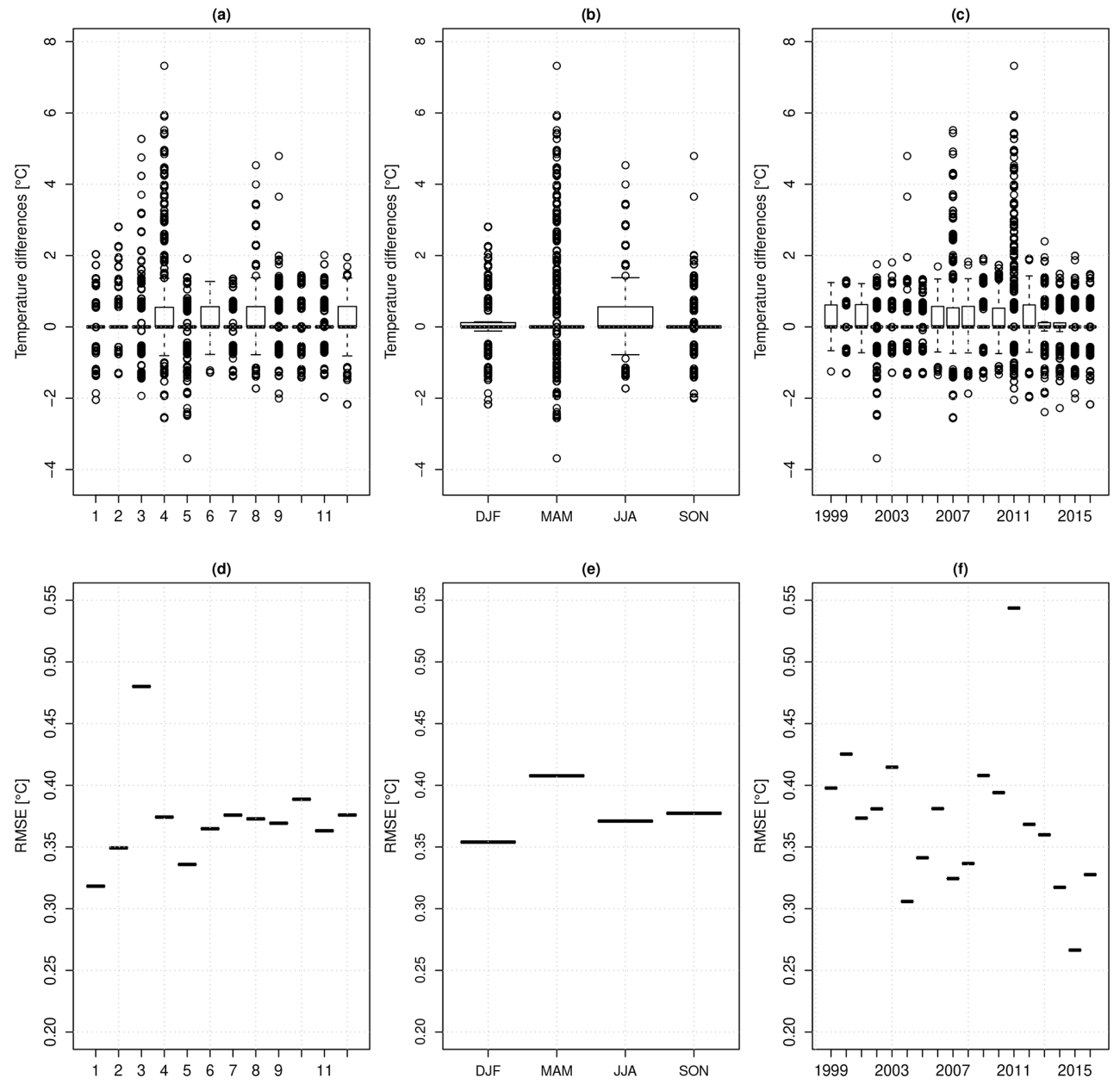

Figure 9. Above: box plots of the differences in temperature between consecutive scenes for individual pixels grouped by month of the year (a), by season (b) and by year (c). Below: Root mean square error of the temperature differences grouped by month of the year (d), by season (e) and by year (f).

on the east side. The problem is due to georeferencing errors which may result in important errors in the temperatures retrieved from satellite images (Sentlinger et al., 2008). In fact, the Lac de Carcans-Hourtin shown in Fig. 10 is located at low altitude and near the sea and the image with path/row 201/029 shows a horizontal displacement of several hundred metres. Geometric accuracy of Landsat images varies with instrument and processing level. For example, Landsat $\mathrm{ETM}+$ nominal accuracy is at least $250 \mathrm{~m} 90 \%$ of the time at the sea level in areas of low relief, while Landsat 5 TM level L1GS images have a geometric accuracy of at least $700 \mathrm{~m}$ $90 \%$ of the time at the sea level in areas of low relief.

\subsection{Satellite image artefacts}

The Landsat website (https://landsat.usgs.gov/known-issues) lists several types of artefacts that can be present in the Landsat data. The artefacts that can affect thermal readings include banding, impulsive noise, coherent noise and memory.
Banding consists of the apparition of bands in the images that can be due to different types of error. Impulsive noise can include both underestimations and overestimations of radiance in individual pixels. It is often linked to problems of transmission or treatment of transcription of the images, but may be due to several reasons. Coherent noise appears in the form of a repetitive noise pattern in the images, which can be caused by different electric systems on board of the satellite. Memory effects are due to the reduced response of the sensor after scanning a bright (hot) target. As a result, if after the bright (hot) target the sensor finds an uniform region like the water surface, the measured values will be slightly lower than in the next scan in the inverse sense, producing a banding (Teillet et al., 2004; NASA, 2011). This artefact could affect surface temperature measurements in water bodies, especially when there are great differences with the surrounding terrain. The thermal band measurements of Landsat 7 ETM+ can be slightly affected by memory effects (Goward et al., 2001). The banding in Landsat 7 images is corrected during 

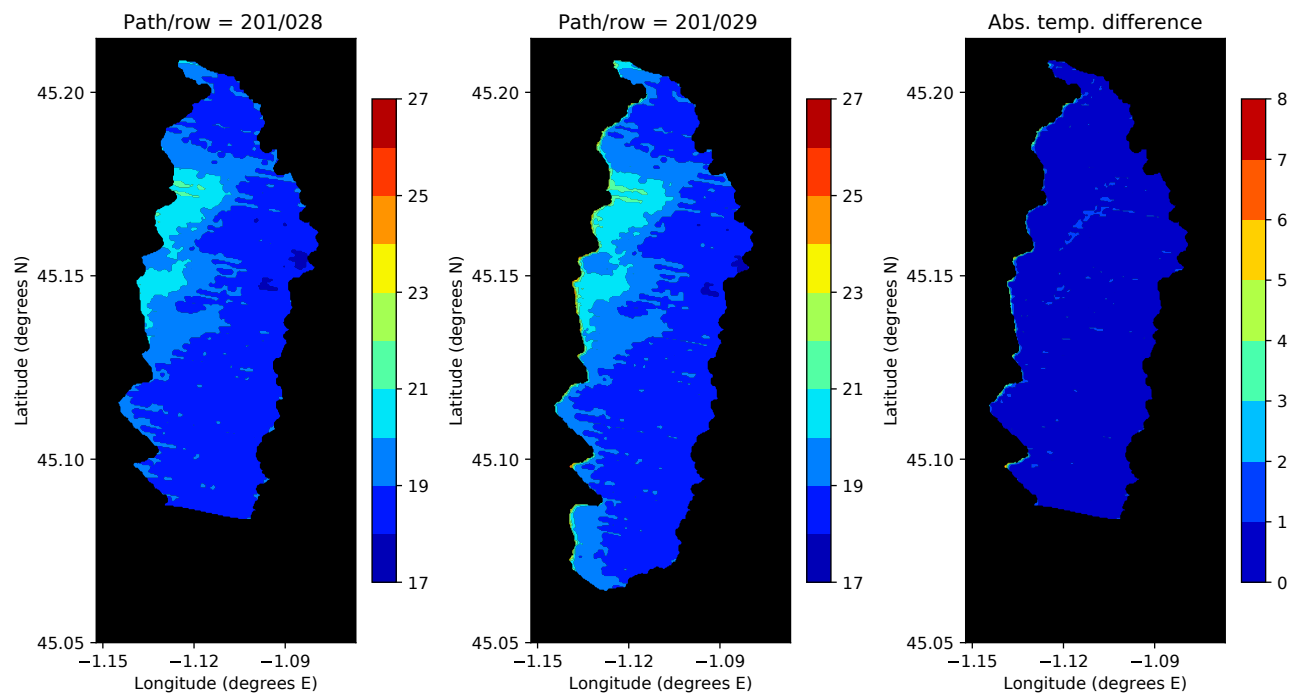

Figure 10. Water temperature according to two overlapping images for the Étang de Carcans-Hourtin (ECH33) on 7 April 2011, and absolute temperature difference between both images.

Table 2. List of pairs of overlapping satellite images with temperature differences higher than $3{ }^{\circ} \mathrm{C}$.

\begin{tabular}{llrl}
\hline Date & Satellite & Path/Row & Water body \\
\hline 12 May 2002 & Landsat 7 & $197 / 030,197 / 031$ & Lac de Matemale (MAT66) \\
22 Sep 2004 & Landsat 7 & $197 / 030,197 / 031$ & Lac de Puyvalador (PUY66) \\
12 Apr 2007 & Landsat 5 & $201 / 028,201 / 029$ & Lac de Carcans-Hourtin (ECH33) \\
22 Mar 2011 & Landsat 5 & $201 / 028,201 / 029$ & Lac de Carcans-Hourtin (ECH33) \\
7 Apr 2011 & Landsat 5 & $201 / 028,201 / 029$ & Lac de Carcans-Hourtin (ECH33) \\
29 Aug 2011 & Landsat 5 & $201 / 028,201 / 029$ & Lac de Carcans-Hourtin (ECH33) \\
\hline
\end{tabular}

image production wherever it is detectable, i.e. in smooth, homogeneous surfaces (ESA, 2003; NASA, 2011). According to Teillet et al. (2004), memory effects have not been observed in the measurements of the thermal band of Landsat $5 \mathrm{TM}$.

We have no measure of the incidence of these artefacts in the database, but we have observed banding in some images (e.g. Fig. 10). Also, in Fig. 10 temperature varies spatially in an east-west direction. Such spatial variability may be due to upwellings caused by the wind (Marti-Cardona et al., 2008). However, the presence of banding may indicate that memory effects are also present. To decrease the impact of artefacts, we recommend using the median temperature for each satellite image. The advantage of using the median is that it is a robust statistic resistant to the effect of extreme values. To validate the spatial variability of temperature in satellite images, several spatially distributed measurements points in a water body would be necessary.

In addition, on 31 May 2003 the Scan Line Corrector of the Landsat 7 satellite failed. As a result, from that moment the measurement scans could not be corrected for the forward motion of the satellite and about $22 \%$ of image data were lost. The gaps are less important in the centre of the image and increase towards the edge. This is known as the Landsat 7 SLC-off issue. Since this problem does not affect the radiometric and geometric corrections (https://landsat.usgs. gov/slc-products-background), SLC-off data could still be used for the creation of the data set and no interpolation was applied to fill the data gaps.

\subsection{Comparison of satellite measurements to field data}

To compare satellite measurements to field data, it is necessary to correct them according to Eq. (2) to account for the cool skin and warm layer effects. However, the performance of the COARE algorithm in the estimation of $\Delta T_{\mathrm{w}}$ was not very good (coefficient of correlation of 0.45 , Sect. 4.3 ) and we prefer not to use it to correct the warm layer effect. Onedimensional hydrodynamic models used by the limnological community do not offer a solution either, since their RMSE is typically $\sim 1-2{ }^{\circ} \mathrm{C}$ (e.g. Read et al., 2014), of the same order of magnitude as the RMSE of the satellite temperature estimations (see below). However, whatever the algorithm the determination of site- and time-specific corrections would still require the use of in situ (i.e. above the water) rarely available meteorological data, because of the microm- 

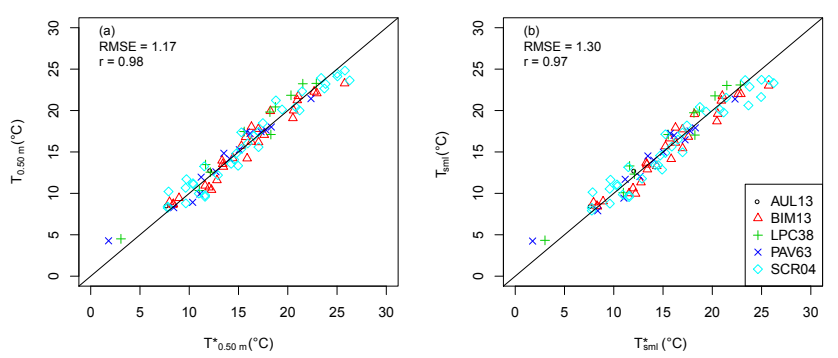

Figure 11. Comparison of satellite-based temperature estimations $\left(T^{*}\right)$ and in situ temperatures $(T)$ : (a) temperature at $0.5 \mathrm{~m},(\mathbf{b})$ temperature of the surface mixed layer. The diagonal line represents the $1: 1$ relation.

eteorological conditions above inland water bodies. For these reasons, we applied the same correction, derived from the results for the reservoir of Bimont, to the five validation sites as a first approach. When more validation data become available, more complex corrections may be envisaged.

The average expected cool skin effect at the reservoir of Bimont was $\Delta T_{\mathrm{c}}=-0.46^{\circ} \mathrm{C}$ (Sect. 4.2) and the average warm layer effect at the time of the satellite overpass was $\Delta T_{\mathrm{w}}(0.50 \mathrm{~m}) \approx 0.07^{\circ} \mathrm{C}$ and $\Delta T_{\mathrm{w}}(\mathrm{sml})=0.12^{\circ} \mathrm{C}$ (Sect. 5.1). So, we estimated surface temperature as

$T_{0.50 \mathrm{~m}}^{*}=T_{\text {skin }}-\Delta T_{\mathrm{c}}-\Delta T_{\mathrm{w}}(0.50 \mathrm{~m})=T_{\text {skin }}+0.39^{\circ} \mathrm{C}$,

$T_{\mathrm{sml}}^{*}=T_{\text {skin }}-\Delta T_{\mathrm{c}}-\Delta T_{\mathrm{w}}(\mathrm{sml})=T_{\text {skin }}+0.34^{\circ} \mathrm{C}$.

The correlation between corrected satellite temperatures and in situ temperatures was good $(\rho=0.97-0.98)$ and the overall RMSE was $1.30^{\circ} \mathrm{C}$ for $T_{\mathrm{sml}}$ and $1.17^{\circ} \mathrm{C}$ for $T_{0.50 \mathrm{~m}}$ (Table 1, Fig. 11). For the overall set of water bodies, the bias of corrected satellite temperatures was not statistically different from zero ( $p$ value $=0.25$ for $T_{\text {sml }}$ and $p$ value $=0.40$ for $T_{0.50 \mathrm{~m}}$ ). However, one of the water bodies (LPC38) showed a bias significantly different from zero at the $\alpha=0.05$ level, probably indicating that the correction was not appropriate for this lake.

These observations improve uncertainty estimations performed in the former study (Simon et al., 2014), which reports coefficients of determination above 0.9 and RMSE of $1-2{ }^{\circ} \mathrm{C}$. The error statistics found for French water bodies are comparable to those found in other studies using satellite images to estimate surface water temperatures. Crosman and Horel (2009) found a cool bias of $-1.5^{\circ} \mathrm{C}$ of MODISderived surface temperatures of the Salt Lake relative to $T_{0.50 \mathrm{~m}}$. Lamaro et al. (2013) used Landsat $7 \mathrm{ETM}+$ thermal images to obtain surface temperatures for the Río Tercero reservoir in Argentina. They obtained an RMSE of $1.2^{\circ} \mathrm{C}$ when using the SC algorithm of Jiménez-Muñoz et al. (2009) and an RMSE of $1.0^{\circ} \mathrm{C}$ when using the Radiative Transfer Method.

The bias showed a seasonal pattern, with underestimations occurring in the months of September to February (Fig. 12). Lamaro et al. (2013) observed that the SC algorithm tended

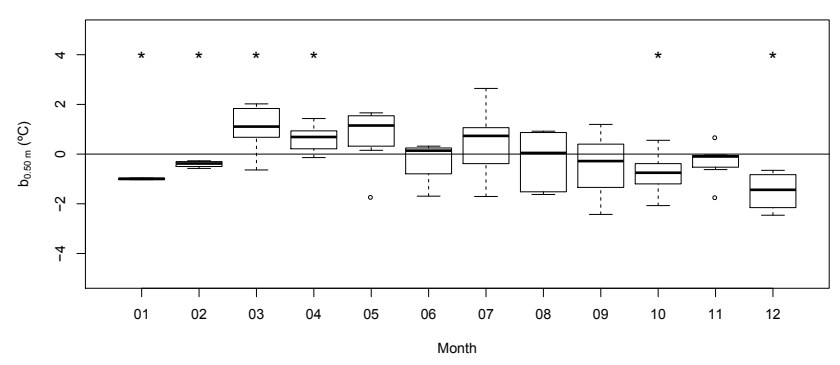

Figure 12. Bias for the temperature at $0.50 \mathrm{~m}$ as a function of the month of the year. Asterisks indicate statistically significant differences from zero at the 0.05 level.

to overestimate water temperatures except in July (winter in the Southern Hemisphere) when they were underestimated. They thought it might be caused by the greater difference between the colder air and the water. Allan et al. (2016) showed that, depending on the sources of atmospheric data, the SC algorithm tended to underestimate or overestimate water surface temperatures.

To find the reason for the observed seasonal bias, we calculated the correlation between $b_{0.50 \mathrm{~m}}$ and several variables: water temperature, atmospheric water content, distance between the measuring station and the nearest valid pixel, daily liquid precipitation, daily air temperature, daily specific humidity, daily wind speed, daily downwelling longwave radiation, daily incoming solar radiation, solar elevation at 10:00 UTC and daily clearness index. To avoid multiple testing issues when assessing the statistical significance of correlations, we used a Bonferroni correction of the significance level using $\alpha=0.05 / 13$ where 13 is the number of tests. The bias was correlated with air temperature $\left(\rho=0.37, p\right.$ value $\left.=2.7 \times 10^{-4}\right)$, daily solar radiation $\left(\rho=0.47, p\right.$ value $\left.=2.3 \times 10^{-6}\right)$ and solar elevation at 10:00 UTC $\left(\rho=0.45, p\right.$ value $\left.=7.3 \times 10^{-6}\right)$. Similar results could be found for $b_{\mathrm{sml}}$. Since some of these variables were correlated among themselves, the number of variables to explain the variability in the bias could be reduced to just 1 by using stepwise model selection by Akaike information criterion:

$b_{0.50 \mathrm{~m}}=-1.51+7.129 \times 10^{-4} R_{\mathrm{s}}$,

$b_{\mathrm{sml}}=-1.56+8.725 \times 10^{-4} R_{\mathrm{s}}$,

where $R_{\mathrm{S}}$ is the downwelling solar radiation $\left(\mathrm{J} \mathrm{cm}^{-2}\right)$. This seasonal pattern might be due to the use of constant average cool skin and warm layer effects in Eqs. (11)-(12). According to the continuous measurements taken at the reservoir of Bimont, there is a positive correlation $(\rho=0.25$, $p$ value $=6.1 \times 10^{-9}$ ) between the warm layer effect and solar radiation at 10:00 UTC for clear-sky conditions. However, in situ radiometric skin temperature measurements would be necessary to prove this point. Also, given the high correlation between $T_{\mathrm{a}}$ and $R_{\mathrm{S}}\left(\rho=0.68, p\right.$ value $\left.=1.3 \times 10^{-13}\right)$, 
the term $R_{\mathrm{S}}$ might partially account for air temperature effects. Although not correlated to emittance, air temperature is well correlated to sky temperature (Aubinet, 1994), affecting the longwave radiation balance. The dependence between air temperature and longwave radiation balance is not taken into account by the SC algorithm. In fact, the results of SC algorithms, including the one used here, can be improved by using $T_{\mathrm{a}}$ in addition to water vapour as input data (Qin et al., 2001; Cristóbal et al., 2009).

\section{Applications}

Satellite data can be used to demonstrate inter-lake spatial and temporal patterns of surface water temperature. A first analysis of spatial patterns was carried by Prats and Danis (2015) using a preliminary version of the database and showing a good correlation between surface temperature and latitude and altitude. Since satellite water temperature measurements are a continuous source of data, they can be used for long-term studies, such as the monitoring of climate change effects. This was demonstrated by Schneider and Hook (2010) and Schneider et al. (2009) by calculating surface temperature trends obtained from AVHRR (Advanced Very High Resolution Radiometers) and ATSR (Along-Track Scanning Radiometer) instruments. Such studies have demonstrated warming rates of $0.11^{\circ} \mathrm{C} \mathrm{yr}^{-1}$ for lakes in California and Nevada over the period 1992-2008 (Schneider et al., 2009) and an average of $0.045^{\circ} \mathrm{C} \mathrm{yr}^{-1}$ over the period 1985-2009 for 167 large inland water bodies worldwide (Schneider and Hook, 2010). Still, the utility of the data set LakeSST for climate change studies is limited by the magnitude of its RMSE $\left(1.16^{\circ} \mathrm{C}\right.$ for $T_{0.50 \mathrm{~m}}^{*}, 1.29^{\circ} \mathrm{C}$ for $T_{\mathrm{sml}}^{*}$ ), which means that longer time series may be necessary to detect long-term trends confidently, as well as more complex corrections of the cool skin and warm layer effects than those proposed here to reduce the level of noise.

Satellite measurements can also be used to complement the data used for the calibration and validation of hydrodynamic and water quality models of lakes. Although these models require profile data, long data series of profile data are still rare and satellite measurements can be useful to provide long-term data for the study at hand. The value of the calibration parameters depends on the available data (Andréassian et al., 2012; Prats and Danis, 2017) and it is interesting to test the long-term performance of a model, especially if it will be used to predict the effects of climate change or similar long-term effects. Satellite measurements have been used to assess the long-term performance of a hydrodynamic model of the reservoir of Bimont (Prats et al., 2018b). Satellite images are particularly useful for the application of two-dimensional and three-dimensional models.

Satellite images can be used to estimate surface fluxes. The knowledge of the surface fluxes of heat and gases is important for research and management. The study of the thermal surface fluxes is important to understand the thermal behaviour of lakes (Henderson-Sellers, 1986). A good estimation of evaporation is necessary to accurately estimate the hydrologic budget of a lake (Sahoo et al., 2013) and allows an estimation of a part of the water footprint of a nation due to artificial water reservoirs (Hoekstra, 2017). These fluxes depend on $T_{\text {int }}$ (Saunders, 1967; Kawai and Wada, 2007); $T_{\text {int }}$ determines the emitted longwave radiation and the value of the saturation vapour pressure at the surface, affecting latent and sensible flux calculations (Webster et al., 1996). The interface temperature $T_{\text {int }}$ is a theoretical value and cannot be known (Donlon et al., 2002). In the absence of such a value, experimental studies often use some form of surface bulk temperature to estimate the heat fluxes of inland water bodies (e.g. Oswald and Rouse, 2004; Binyamin et al., 2006; Ramos-Fuertes et al., 2016). However, sea models show that the skin effect on surface heat flux calculations can be of a few tens of watts per square metre (Fairall et al., 1996a; Webster et al., 1996) and it can also affect the exchange of gases (Kawai and Wada, 2007). Satellite images can be used to improve the accuracy of the estimations (Lofgren and Zhu, 2000 ), assuming that $T_{\text {skin }}$ is close enough to $T_{\text {int }}$ (Kawai and Wada, 2007).

\section{Data availability}

The LakeSST data set is distributed under a Creative Commons Attribution 4.0 License. The data may be downloaded from the data repository Zenodo at https://doi.org/10.5281/ zenodo.1193745 (Prats et al., 2018a). The original temperature ASCII rasters used to derive the data set may be obtained by request from the authors.

\section{Conclusions}

The LakeSST data set contains skin surface water temperature data for 442 French water bodies for the period 1999 2016 obtained from archives of Landsat 5 and Landsat 7 thermal infrared images. The overall RMSE of the satellitederived temperature measurements is about $1.2^{\circ} \mathrm{C}$, similar to other applications of satellite images to estimate freshwater surface temperatures. The spatial and temporal coverage of the database make it an ideal resource for studies on the temporal evolution of lake surface temperature and for geographical studies of temperature patterns.

Since cool skin and warm layer algorithms have been developed mainly for the sea and have not been extensively tested in a freshwater environment - except in extreme cases such as cooling ponds (Wesely, 1979; Adams et al., 1990) - and the warm layer correction estimated by the COARE algorithm using SAFRAN meteorological data was not satisfactory, we provide the satellite temperature data "as is", without applying any correction, leaving the user free to decide which correction to apply, if necessary. In fact, in some 
cases (e.g. studies on surface fluxes) a correction may not be necessary. If a cool skin correction is used (i.e. if the user is interested in the temperature of the first $1-2 \mathrm{~m}$ ), we recommend using one of those which can take into account the differences in the physical characteristics between freshwater and seawater and an appropriate parameterisation of the solar radiation absorption in the water column.

We suggest using the median temperature for each image as an estimation of the average surface temperature of each water body on the measurement date. The estimated temperatures show a seasonal bias that depends on incoming solar radiation. This problem may be solved by applying Eqs. (13) or (14).

\section{The Supplement related to this article is available online at https://doi.org/10.5194/essd-10-727-2018-supplement.}

Author contributions. TT supervised the downloading and processing of satellite images and designed the methodology. NR contributed to downloading satellite images, maintaining and improving script processing and performance, and processing images with PAD. DR, TP and PAD designed, installed and operated the $0.55 \mathrm{~m}$ thermistor chain at the reservoir of Bimont and the full-length thermistor chains of the continuous lake monitoring network. JP calculated summary statistics of the satellite images and prepared the data set LakeSST. JP and PAD made the quality assessment of satellite images. JP prepared the paper with contributions from the other co-authors. All authors have read and approved the final paper.

Competing interests. The authors declare that they have no conflict of interest.

Acknowledgements. This study was funded by the Onema (French National Office for Water and Aquatic Environments) actions 61B, 102 and CK. The authors thank Ricardo Simon for his contribution in preparing the script to process satellite images. The authors thank Météo-France for the meteorological data at the station of Aix-en-Provence and the data from the SAFRAN analysis, provided free of charge to Irstea for this study and for the project "Temperature and oxygen indicators for lakes". The authors are grateful to ECMWF and USGS for providing the data used in producing the surface temperature data set. Special thanks to Julien Dublon, Thierry Point, Jean-Michel Foissy, Michael Cagnant, Jean-Claude Raymond, William Sremski, Gaël Olivier, Sylvain Richard, Philippe Moullec, Laurent Tachot and the agents of the Departmental Services of the French Agency for Biodiversity for the departments 04, 05, 13, 38 and 63. The authors thank the Société du Canal de Provence for granting access to the reservoir of Bimont. The authors thank the two anonymous reviewers for their useful comments.

Edited by: David Carlson

Reviewed by: two anonymous referees

\section{References}

Adams, E. E., Cosler, D. J., and Helfrich, K. R.: Evaporation from heated water bodies: Predicting combined forced plus free convection, Water Resour. Res., 26, 425-435, https://doi.org/10.1029/WR026i003p00425, 1990.

Allan, M. G., Hamilton, D. P., Trolle, D., Muraoka, K., and McBride, C.: Spatial heterogeneity in geothermallyinfluenced lakes derived from atmospherically corrected Landsat thermal imagery and three-dimensional hydrodynamic modelling, Int. J. Appl. Earth Obs., 50, 106-116, https://doi.org/10.1016/j.jag.2016.03.006, 2016.

Andréassian, V., Le Moine, N., Perrin, C., Ramos, M.-H., Oudin, L., Mathevet, T., Lerat, J., and Berthet, L.: All that glitters is not gold: the case of calibrating hydrological models, Hydrol. Process., 26, 2206-2210, https://doi.org/10.1002/hyp.9264, 2012.

Aubinet, M.: Longwave sky radiation parametrizations, Sol. Energy, 53, 147-154, https://doi.org/10.1016/0038092X(94)90475-8, 1994.

Barsi, J. A., Schott, J. R., Palluconi, F. D., Helder, D. L., Hook, S. J., Markham, B. L., Chander, G., and O'Donnell, E. M.: Landsat $\mathrm{TM}$ and ETM+ thermal band calibration, Can. J. Remote Sens., 29, 141-153, https://doi.org/10.5589/m02-087, 2003.

Binyamin, J., Rouse, W. R., Davies, J. A., Oswald, C. J., and Schertzer, W. M.: Surface energy balance calculations for small northern lakes, Int. J. Climatol., 26, 2261-2273, https://doi.org/10.1002/joc.1365, 2006.

Cardenas, M. B., Harvey, J. W., Packman, A. I., and Scott, D. T.: Ground-based thermography of fluvial systems at low and high discharge reveals potential complex thermal heterogeneity driven by flow variation and bioroughness, Hydrol. Process., 22, 980986, https://doi.org/10.1002/hyp.6932, 2008.

Chen, S. F., Chan, R. C., Read, S. M., and Bromley, L. A.: Viscosity of sea water solutions, Desalination, 13, 37-51, https://doi.org/10.1016/S0011-9164(00)80090-9, 1973.

Cristóbal, J., Jiménez-Muñoz, J. C., Sobrino, J. A., Ninyerola, M., and Pons, X.: Improvements in land surface temperature retrieval from the Landsat series thermal band using water vapor and air temperature, J. Geophys. Res.-Atmos., 114, D08103, https://doi.org/10.1029/2008JD010616, 2009.

Crosman, E. T. and Horel, J. D.: MODIS-derived surface temperature of the Great Salt Lake, Remote Sens. Environ., 113, 73-81, https://doi.org/10.1016/j.rse.2008.08.013, 2009.

Dee, D. P., Uppala, S. M., Simmons, A. J., Berrisford, P., Poli, P., Kobayashi, S., Andrae, U., Balmaseda, M. A., Balsamo, G., Bauer, P., Bechtold, P., Beljaars, A. C. M., van de Berg, L., Bidlot, J., Bormann, N., Delsol, C., Dragani, R., Fuentes, M., Geer, A. J., Haimberger, L., Healy, S. B., Hersbach, H., Hólm, E. V., Isaksen, L., Kållberg, P., Köhler, M., Matricardi, M., McNally, A. P., Monge-Sanz, B. M., Morcrette, J. J., Park, B. K., Peubey, C., de Rosnay, P., Tavolato, C., Thépaut, J. N., and Vitart, F.: The ERA-Interim reanalysis: configuration and performance of the data assimilation system, Q. J. Roy. Meteor. Soc., 137, 553-597, https://doi.org/10.1002/qj.828, 2011.

Díaz-Delgado, R., Ameztoy, I., Cristóbal, J., and Bustamante, J.: Long time series of Landsat images to reconstruct River surface temperature and turbidity regimes of Guadalquivir Estuary, 2010 IEEE International Geoscience and Remote Sensing Symposium, 233-236, 2010. 
Donlon, C., Rayner, N., Robinson, I., Poulter, D. J. S., Casey, K. S., Vazquez-Cuervo, J., Armstrong, E., Bingham, A., Arino, O., Gentemann, C., May, D., LeBorgne, P., Piollé, J., Barton, I., Beggs, H., Merchant, C. J., Heinz, S., Harris, A., Wick, G., Emery, B., Minnett, P., Evans, R., Llewellyn-Jones, D., Mutlow, C., Reynolds, R. W., and Kawamura, H.: The Global Ocean Data Assimilation Experiment High-resolution Sea Surface Temperature Pilot Project, B. Am. Meteorol. Soc., 88, 1197-1213, https://doi.org/10.1175/bams-88-8-1197, 2007.

Donlon, C. J., Nightingale, T. J., Sheasby, T., Turner, J., Robinson, I. S., and Emergy, W. J.: Implications of the oceanic thermal skin temperature deviation at high wind speed, Geophys. Res. Lett., 26, 2505-2508, https://doi.org/10.1029/1999GL900547, 1999.

Donlon, C. J., Minnett, P. J., Gentemann, C., Nightingale, T. J., Barton, I. J., Ward, B., and Murray, M. J.: Toward Improved Validation of Satellite Sea Surface Skin Temperature Measurements for Climate Research, J. Climate, 15, 353-369, https://doi.org/10.1175/15200442(2002)015<0353:tivoss>2.0.co;2, 2002.

Dörnhöfer, K. and Oppelt, N.: Remote sensing for lake research and monitoring - Recent advances, Ecol. Indic., 64, 105-122, https://doi.org/10.1016/j.ecolind.2015.12.009, 2016.

ESA: Banding, ESA, on line, 7, available at: https://earth.esa.int/c/ document_library/get_file?folderId=25717\&name=DLFE-524. pdf, 2003.

Fairall, C. W., Bradley, E. F., Godfrey, J. S., Wick, G. A., Edson, J. B., and Young, G. S.: Cool-skin and warm-layer effects on sea surface temperature, J. Geophys. Res.-Oceans, 101, 1295-1308, https://doi.org/10.1029/95JC03190, 1996a.

Fairall, C. W., Bradley, E. F., Rogers, D. P., Edson, J. B., and Young, G. S.: Bulk parameterization of air-sea fluxes for Tropical Ocean-Global Atmosphere Coupled-Ocean Atmosphere Response Experiment, J. Geophys. Res.-Oceans, 101, 3747-3764, https://doi.org/10.1029/95JC03205, 1996b.

Fairall, C. W., Bradley, E. F., Hare, J. E., Grachev, A. A., and Edson, J. B.: Bulk Parameterization of Air-Sea Fluxes: Updates and Verification for the COARE Algorithm, J. Climate, 16, 571-591, https://doi.org/10.1175/15200442(2003)016<0571: bpoasf>2.0.co;2, 2003.

Gentemann, C. L. and Minnett, P. J.: Radiometric measurements of ocean surface thermal variability, J. Geophys. Res.-Oceans, 113, C08017, https://doi.org/10.1029/2007JC004540, 2008.

Gentemann, C. L., Donlon, C. J., Stuart-Menteth, A., and Wentz, F. J.: Diurnal signals in satellite sea surface temperature measurements, Geophys. Res. Lett., 30, 1140, https://doi.org/10.1029/2002GL016291, 2003.

Gentemann, C. L., Minnett, P. J., and Ward, B.: Profiles of ocean surface heating (POSH): A new model of upper ocean diurnal warming, J. Geophys. Res.-Oceans, 114, C07017, https://doi.org/10.1029/2008JC004825, 2009.

Gerace, A. and Montanaro, M.: Derivation and validation of the stray light correction algorithm for the thermal infrared sensor onboard Landsat 8, Remote Sens. Environ., 191, 246-257, https://doi.org/10.1016/j.rse.2017.01.029, 2017.

Goward, S. N., Masek, J. G., Williams, D. L., Irons, J. R., and Thompson, R. J.: The Landsat 7 mission: Terrestrial research and applications for the 21st century, Remote Sens. Environ., 78, 312, https://doi.org/10.1016/S0034-4257(01)00262-0, 2001.
Hamilton, D. P., Carey, C. C., Arvola, L., Arzberger, P., Brewer, C., Cole, J. J., Gaiser, E., Hanson, P. C., Ibelings, B. W., Jennings, E., Kratz, T. K., Lin, F.-P., McBride, C. G., David de Marques, M., Muraoka, K., Nishri, A., Qin, B., Read, J. S., Rose, K. C., Ryder, E., Weathers, K. C., Zhu, G., Trolle, D., and Brookes, J. D.: A Global Lake Ecological Observatory Network (GLEON) for synthesising high-frequency sensor data for validation of deterministic ecological models, Inland Waters, 5, 49-56, https://doi.org/10.5268/IW-5.1.566, 2015.

Henderson-Sellers, B.: Calculating the surface energy balance for lake and reservoir modeling: A review, Rev. Geophys., 24, 625649, https://doi.org/10.1029/RG024i003p00625, 1986.

Hoekstra, A. Y.: Water Footprint Assessment: Evolvement of a New Research Field, Water Resour. Manage., 31, 3061-3081, https://doi.org/10.1007/s11269-017-1618-5, 2017.

Hook, S. J., Chander, G., Barsi, J. A., Alley, R. E., Abtahi, A., Palluconi, F. D., Markham, B. L., Richards, R. C., Schladow, S. G., and Helder, D. L.: In-flight validation and recovery of water surface temperature with Landsat-5 thermal infrared data using an automated high-altitude lake validation site at Lake Tahoe, IEEE T. Geosci. Remote, 42, 2767-2776, https://doi.org/10.1109/TGRS.2004.839092, 2004.

Horrocks, L. A., Candy, B., Nightingale, T. J., Saunders, R. W., O'Carroll, A., and Harris, A. R.: Parameterizations of the ocean skin effect and implications for satellite-based measurement of sea-surface temperature, J. Geophys. Res.-Oceans, 108, 3096, https://doi.org/10.1029/2002JC001503, 2003.

Hunter, J. D.: Matplotlib: A 2D Graphics Environment, Comput. Sci. Eng., 9, 90-95, https://doi.org/10.1109/MCSE.2007.55, 2007.

Imberger, J.: The diurnal mixed layer, Limnol. Oceanogr., 30, 737 770, https://doi.org/10.4319/lo.1985.30.4.0737, 1985.

Jiménez-Muñoz, J. C. and Sobrino, J. A.: A generalized singlechannel method for retrieving land surface temperature from remote sensing data, J. Geophys. Res.-Atmos., 108, 4688, https://doi.org/10.1029/2003JD003480, 2003.

Jiménez-Muñoz, J. C., Cristóbal, J., Sobrino, J. A., Sòria, G., Ninyerola, M., and Pons, X.: Revision of the single-channel algorithm for land surface temperature retrieval from Landsat thermal-infrared data, IEEE T. Geosci. Remote, 47, 339-349, https://doi.org/10.1109/TGRS.2008.2007125, 2009.

Kantha, L. H. and Clayson, C. A.: An improved mixed layer model for geophysical applications, J. Geophys. Res.-Oceans, 99, 25235-25266, https://doi.org/10.1029/94JC02257, 1994.

Kawai, Y. and Kawamura, H.: Study on a Platform Effect in the In Situ Sea Surface Temperature Observations under Weak Wind and Clear Sky Conditions Using Numerical Models, J. Atmos. Ocean. Tech., 17, 185-196, https://doi.org/10.1175/15200426(2000)017<0185:soapei>2.0.co;2, 2000.

Kawai, Y. and Wada, A.: Diurnal sea surface temperature variation and its impact on the atmosphere and ocean: A review, J. Oceanogr., 63, 721-744, https://doi.org/10.1007/s10872-0070063-0, 2007.

Kawai, Y., Ando, K., and Kawamura, H.: Distortion of Near-Surface Seawater Temperature Structure by a Moored-Buoy Hull and Its Effect on Skin Temperature and Heat Flux Estimates, Sensors, 9, 6119-6130, 2009.

Kettle, H., Thompson, R., Anderson, N. J., and Livingstone, D. M.: Empirical modeling of summer lake surface tempera- 
tures in southwest Greenland, Limnol. Oceanogr., 49, 271-282, https://doi.org/10.4319/lo.2004.49.1.0271, 2004.

Laas, A., de Eyto, E., Pierson, D., and Jennings, E.: NETLAKE Guidelines for automatic monitoring station development, available at: http://eprints.dkit.ie/id/eprint/524 (last access: 13 November 2017), Technical report NETLAKE COST Action ES1201, 58, 2016.

Lalot, E., Curie, F., Wawrzyniak, V., Baratelli, F., Schomburgk, S., Flipo, N., Piegay, H., and Moatar, F.: Quantification of the contribution of the Beauce groundwater aquifer to the discharge of the Loire River using thermal infrared satellite imaging, Hydrol. Earth Syst. Sci., 19, 4479-4492, https://doi.org/10.5194/hess-194479-2015, 2015.

Lamaro, A. A., Mariñelarena, A., Torrusio, S. E., and Sala, S. E.: Water surface temperature estimation from Landsat $7 \mathrm{ETM}+$ thermal infrared data using the generalized single-channel method: Case study of Embalse del Río Tercero (Córdoba, Argentina), Adv. Space Res., 51, 492-500, https://doi.org/10.1016/j.asr.2012.09.032, 2013.

Lenoble, J.: The solar radiation received on the Earth, in: Atmospheric radiative transfer, edited by: Lenoble, J., A. Deepak Publishing, Hampton, 223-237, 1993.

Li, Z.-L., Tang, B.-H., Wu, H., Ren, H., Yan, G., Wan, Z., Trigo, I. F., and Sobrino, J. A.: Satellite-derived land surface temperature: Current status and perspectives, Remote Sens. Environ., 131, 1437, https://doi.org/10.1016/j.rse.2012.12.008, 2013.

Lofgren, B. M. and Zhu, Y.: Surface Energy Fluxes on the Great Lakes Based on Satellite-Observed Surface Temperatures 1992 to 1995, J. Great Lakes Res., 26, 305-314, https://doi.org/10.1016/S0380-1330(00)70694-0, 2000.

Marcé, R., George, G., Buscarinu, P., Deidda, M., Dunalska, J., de Eyto, E., Flaim, G., Grossart, H.-P., Istvanovics, V., Lenhardt, M., Moreno-Ostos, E., Obrador, B., Ostrovsky, I., Pierson, D. C., Potužák, J., Poikane, S., Rinke, K., Rodríguez-Mozaz, S., Staehr, P. A., Šumberová, K., Waajen, G., Weyhenmeyer, G. A., Weathers, K. C., Zion, M., Ibelings, B. W., and Jennings, E.: Automatic High Frequency Monitoring for Improved Lake and Reservoir Management, Environ. Sci. Technol., 50, 1078010794, https://doi.org/10.1021/acs.est.6b01604, 2016.

Marti-Cardona, B., Steissberg, T. E., Schladow, S. G., and Hook, S. J.: Relating fish kills to upwellings and wind patterns in the Salton Sea, Hydrobiologia, 604, 85-95, https://doi.org/10.1007/s10750-008-9315-2, 2008.

Martí-Cardona, B., Arbat-Bofill, M., Prats-Rodríguez, J., and Pipia, L.: Thermal remote sensing for reservoir modelling and management, Living Planet Symposium 2016, Prague, Czech Republic, 9-13 May 2016, 2016.

Masek, J. G., Vermote, E. F., Saleous, N. E., Wolfe, R., Hall, F. G., Huemmrich, K. F., Gao, F., Kutler, J., and Lim, T.K.: A Landsat surface reflectance dataset for North America, 1990-2000, IEEE Geosci. Remote Sens. Lett., 3, 68-72, https://doi.org/10.1109/LGRS.2005.857030, 2006.

Masuda, K., Takashima, T., and Takayama, Y.: Emissivity of pure and sea waters for the model sea surface in the infrared window regions, Remote Sens. Environ., 24, 313-329, https://doi.org/10.1016/0034-4257(88)90032-6, 1988.

McKinney, W.: Data Structures for Statistical Computing in Python, 9th Python in Science Conference (SciPy 2010), Austin, Texas, 2010, 51-56, 2010.
Minnett, P. J., Smith, M., and Ward, B.: Measurements of the oceanic thermal skin effect, Deep-Sea Res. Pt. II, 58, 861-868, https://doi.org/10.1016/j.dsr2.2010.10.024, 2011.

Montanaro, M., Gerace, A., Lunsford, A., and Reuter, D.: Stray Light Artifacts in Imagery from the Landsat 8 Thermal Infrared Sensor, Remote Sens.-Basel, 6, 10435-10456, 2014.

NASA: Landsat 7 Science Data Users Handbook, Landsat Project Science Office, on line, available at: https://landsat.gsfc.nasa. gov/landsat-7-science-data-users-handbook/ (last access: 25 April 2017), 2011.

Ohlmann, J. C. and Siegel, D. A.: Ocean Radiant Heating. Part II: Parameterizing Solar Radiation Transmission through the Upper Ocean, J. Phys. Oceanogr., 30, 1849-1865, https://doi.org/10.1175/15200485(2000)030<1849:orhpip>2.0.co;2, 2000.

O'Reilly, C. M., Alin, S. R., Plisnier, P.-D., Cohen, A. S., and McKee, B. A.: Climate change decreases aquatic ecosystem productivity of Lake Tanganyika, Africa, Nature, 424, 766-768, https://doi.org/10.1038/nature01833, 2003.

Oppenheimer, C.: Ramifications of the skin effect for crater lake heat budget analysis, J. Volcanol. Geoth. Res., 75, 159-165, https://doi.org/10.1016/S0377-0273(96)00037-6, 1997.

Oswald, C. J. and Rouse, W. R.: Thermal Characteristics and Energy Balance of Various-Size Canadian Shield Lakes in the Mackenzie River Basin, J. Hydrometeorol., 5, 129-144, https://doi.org/10.1175/15257541(2004)005<0129:tcaebo>2.0.co;2, 2004.

Politi, E., Cutler, M. E. J., and Rowan, J. S.: Using the NOAA Advanced Very High Resolution Radiometer to characterise temporal and spatial trends in water temperature of large European lakes, Remote Sens. Environ., 126, 1-11, https://doi.org/10.1016/j.rse.2012.08.004, 2012.

Prats, J. and Danis, P.-A.: Optimisation du réseau national de suivi pérenne in situ de la température des plans d'eau : apport de la modélisation et des données satellitaires, Rapport final., Onema, Aix-en-Provence, 94, 2015.

Prats, J. and Danis, P.-A.: Assessment of the single-ensemble method applied to hydrodynamic simulations, Limnetica, 36, 114, https://doi.org/10.23818/limn.36.01, 2017.

Prats, J., Reynaud, N., Tormos, T., and Danis, P.-A.: LakeSST: Lake Skin Surface Temperature in French inland water bodies (Version 1.2) [Data set], Zenodo, https://doi.org/10.5281/zenodo.1193745, 2018a.

Prats, J., Salençon, M.-J., Gant, M., and Danis, P.-A.: Simulation of the hydrodynamic behaviour of a Mediterranean reservoir under different climate change and management scenarios, J. Limnol., 77, 62-81, https://doi.org/10.4081/jlimnol.2017.1567, 2018b.

Price, J. F., Weller, R. A., and Pinkel, R.: Diurnal cycling: Observations and models of the upper ocean response to diurnal heating, cooling, and wind mixing, J. Geophys. Res.-Oceans, 91, 84118427, https://doi.org/10.1029/JC091iC07p08411, 1986.

Qin, Z., Karnieli, A., and Berliner, P.: A mono-window algorithm for retrieving land surface temperature from Landsat TM data and its application to the Israel-Egypt border region, Int. J. Remote Sens., 22, 3719-3746, https://doi.org/10.1080/01431160010006971, 2001.

Quintana-Seguí, P., Le Moigne, P., Durand, Y., Martin, E., Habets, F., Baillon, M., Canellas, C., Franchisteguy, L., and Morel, S.: Analysis of Near-Surface Atmospheric Variables: Validation of 
the SAFRAN Analysis over France, J. Appl. Meteorol., 47, 92107, https://doi.org/10.1175/2007jamc1636.1, 2008.

Ramos-Fuertes, A., Prats, J., and Dolz, J.: Balances de agua y calor en la marisma de Doñana, Ingeniería del Agua, 20, 169-179, https://doi.org/10.4995/ia.2016.4720, 2016.

R Core Team: R: A language and environment for statistical computing, R Foundation for Statistical Computing, on line, available at: http://www.R-project.org (last access: 9 April 2018), 2015.

Read, J. S., Winslow, L. A., Hansen, G. J. A., Van Den Hoek, J., Hanson, P. C., Bruce, L. C., and Markfort, C. D.: Simulating 2368 temperate lakes reveals weak coherence in stratification phenology, Ecol. Model., 291, 142-150, https://doi.org/10.1016/j.ecolmodel.2014.07.029, 2014.

Rebière, D., Danis, P.-A., Dublon, J., Baudoin, J.-M., and Daufresne, M.: Réseau de suivi pérenne de la température des plans d'eau: Synthèse de la phase de test, 54, 2014.

Sahoo, G. B., Schladow, S. G., and Reuter, J. E.: Hydrologic budget and dynamics of a large oligotrophic lake related to hydro-meteorological inputs, J. Hydrol., 500, 127-143, https://doi.org/10.1016/j.jhydrol.2013.07.024, 2013.

Saunders, P. M.: The Temperature at the Ocean-Air Interface, J. Atmos. Sci., 24, 269-273, https://doi.org/10.1175/15200469(1967)024<0269:ttatoa>2.0.co;2, 1967.

Schneider, P. and Hook, S. J.: Space observations of inland water bodies show rapid surface warming since 1985, Geophys. Res. Lett., 37, L22405, https://doi.org/10.1029/2010GL045059, 2010.

Schneider, P., Hook, S. J., Radocinski, R. G., Corlett, G. K., Hulley, G. C., Schladow, S. G., and Steissberg, T. E.: Satellite observations indicate rapid warming trend for lakes in California and Nevada, Geophys. Res. Lett., 36, L22402, https://doi.org/10.1029/2009GL040846, 2009.

Sentlinger, G. I., Hook, S. J., and Laval, B.: Sub-pixel water temperature estimation from thermal-infrared imagery using vectorized lake features, Remote Sens. Environ., 112, 1678-1688, https://doi.org/10.1016/j.rse.2007.08.019, 2008.

Sharqawy, M. H., Lienhard, J. H., and Zubair, S. M.: Thermophysical properties of seawater: a review of existing correlations and data, Desalin. Water Treat., 16, 354-380, https://doi.org/10.5004/dwt.2010.1079, 2010.

Shuter, B. J. and Post, J. R.: Climate, Population Viability, and the Zoogeography of Temperate Fishes, Trans. Am. Fish. Soc., 119, 314-336, https://doi.org/10.1577/15488659(1990)119<0314:cpvatz>2.3.co;2, 1990.

Simon, R. N., Tormos, T., and Danis, P.-A.: Retrieving water surface temperature from archive LANDSAT thermal infrared data: Application of the mono-channel atmospheric correction algorithm over two freshwater reservoirs, Int. J. Appl. Earth Obs., 30, $247-$ 250, https://doi.org/10.1016/j.jag.2014.01.005, 2014.

Sobrino, J. A., Jiménez-Muñoz, J. C., and Paolini, L.: Land surface temperature retrieval from LANDSAT TM 5, Remote Sens. Environ., 90, 434-440, https://doi.org/10.1016/j.rse.2004.02.003, 2004.

Teillet, P. M., Helder, D. L., Ruggles, T. A., Landry, R., Ahern, F. J., Higgs, N. J., Barsi, J., Chander, G., Markham, B. L., Barker, J. L., Thome, K. J., Schott, J. R., and Palluconi, F. D.: A definitive calibration record for the Landsat-5 thematic mapper anchored to the Landsat-7 radiometric scale, Can. J. Remote Sens., 30, 631643, https://doi.org/10.5589/m04-022, 2004.
Toffolon, M., Piccolroaz, S., Majone, B., Soja, A.-M., Peeters, F., Schmid, M., and Wüest, A.: Prediction of surface temperature in lakes with different morphology using air temperature, Limnol. Oceanogr., 59, 2185-2202, https://doi.org/10.4319/lo.2014.59.6.2185, 2014.

Torbick, N., Ziniti, B., Wu, S., and Linder, E.: Spatiotemporal Lake Skin Summer Temperature Trends in the Northeast United States, Earth Interact., 20, 1-21, https://doi.org/10.1175/ei-d-160015.1, 2016.

Trunk, L. and Bernard, A.: Investigating crater lake warming using ASTER thermal imagery: Case studies at Ruapehu, Poás, Kawah Ijen, and Copahué Volcanoes, J. Volcanol. Geoth. Res., 178, 259270, https://doi.org/10.1016/j.jvolgeores.2008.06.020, 2008.

van der Walt, S., Colbert, S. C., and Varoquaux, G.: The NumPy Array: A Structure for Efficient Numerical Computation, Comput. Sci. Eng., 13, 22-30, https://doi.org/10.1109/MCSE.2011.37, 2011.

Venables, W. N. and Ripley, B. D.: Modern applied statistics with S, 4th edition ed., Springer, New York, 2002.

Verpoorter, C., Kutser, T., Seekell, D. A., and Tranvik, L. J.: A global inventory of lakes based on high-resolution satellite imagery, Geophys. Res. Lett., 41, 6396-6402, https://doi.org/10.1002/2014GL060641, 2014.

Vidal, J.-P., Martin, E., Franchistéguy, L., Baillon, M., and Soubeyroux, J.-M.: A 50-year high-resolution atmospheric reanalysis over France with the Safran system, Int. J. Climatol., 30, 1627 1644, https://doi.org/10.1002/joc.2003, 2010.

Ward, B.: Near-surface ocean temperature, J. Geophys. Res.Oceans, 111, C02004, https://doi.org/10.1029/2004JC002689, 2006.

Webster, P. J., Clayson, C. A., and Curry, J. A.: Clouds, Radiation, and the Diurnal Cycle of Sea Surface Temperature in the Tropical Western Pacific, J. Climate, 9, 1712-1730, https://doi.org/10.1175/15200442(1996)009<1712:cratdc>2.0.co;2, 1996.

Wen-Yao, L., Field, R. T., Gantt, R. G., and Klemas, V.: Measurement of the surface emissivity of turbid waters, Remote Sens. Environ., 21, 97-109, https://doi.org/10.1016/00344257(87)90009-5, 1987.

Wesely, M. L.: Heat transfer through the thermal skin of a cooling pond with waves, J. Geophys. Res.-Oceans, 84, 3696-3700, https://doi.org/10.1029/JC084iC07p03696, 1979.

Wick, G. A., Ohlmann, J. C., Fairall, C. W., and Jessup, A. T.: Improved Oceanic Cool-Skin Corrections Using a Refined Solar Penetration Model, J. Phys. Oceanogr., 35, 1986-1996, https://doi.org/10.1175/jpo2803.1, 2005.

Wilson, R. C., Hook, S. J., Schneider, P., and Schladow, S. G.: Skin and bulk temperature difference at Lake Tahoe: A case study on lake skin effect, J. Geophys. Res.-Atmos., 118, 10332-10346, https://doi.org/10.1002/jgrd.50786, 2013.

Winslow, L., Read, J., Woolway, R., Brentrup, J., Leach, T., and Zwart, J.: rLakeAnalyzer: Lake Physics Tools. R package version 1.8.3, on line, available at: http://CRAN.R-project.org/package= rLakeAnalyzer, last access: 1 June, 2016.

Zoran, M.: Nuclear power plant's water thermal plume assessment by satellite remote sensing data, Proceedings of the Global Conference on Global Warming 2011, Lisbon, Portugal, 11-14 July, 2011. 